University of Chicago Law School

Chicago Unbound

Journal Articles

Scholarship

2006

The Federal Judicial Power and the International Legal Order

Curtis A. Bradley

Follow this and additional works at: https://chicagounbound.uchicago.edu/journal_articles

Part of the Law Commons 


\section{THE FEDERAL JUDICIAL POWER AND THE INTERNATIONAL LEGAL ORDER}

Richard Falk famously argued that domestic courts should operate as "agents of the international order." Recent academic debates over the role of international law in the U.S. legal system, and over the relevance of foreign and international materials in U.S. constitutional interpretation, are at least in part debates about this proposition. Modern variants of Falk's claim can be found in the works of scholars such as Harold Koh, Jennifer Martinez, and AnneMarie Slaughter. ${ }^{2}$ These and other "internationalist" scholars consider the U.S. judiciary as part of a "global community of courts," emphasize the values of international cross-fertilization and harmonization, and view international law as directly permeating, and often having primacy within, the U.S. legal system. "Constitutionalist" or "revisionist" scholars, by contrast, distinguish between the international and domestic legal systems, emphasize constitutional structure as a limitation on the domestic effect of international law, and generally advocate political branch rather than judicial control over the domestic implementation of international legal obliga-

Curtis A. Bradley is the Richard and Marcy Horvitz Professor of Law at Duke Law School. Aurhor's note: Thanks to Kathy Bradley, Jack Goldsmith, Joost Pauwelyn, Eric Posner, Paul Stephan, Carlos Vazquez, Mark Weisburd, and Ernest Young for helpful comments.

' Richard A. Falk, The Role of Domestic Courts in the International Legal Order 72 (1964).

2 See, e.g., Harold Hongju Koh, Transnational Legal Process, 75 Neb L Rev 181 (1996); Jennifer Martinez, Towards an International 7udicial System, 56 Stan L Rev 429 (2003); Anne-Marie Slaughter, fudicial Globalization, 40 Va J Intl L 1103 (2000). 
tions. ${ }^{3}$ The leading judicial proponent of the internationalist perspective is currently Justice Breyer; the leading judicial proponent of the constitutionalist perspective is currently Justice Scalia.

Debates between internationalists and constitutionalists encompass a wide variety of legal issues. These issues include the status in the U.S. legal system of customary international law, the circumstances under which treaties are domestically enforceable, the extent to which the federal government can delegate regulatory functions to international actors, and the relevance of federalism to U.S. foreign relations. The practical significance of these debates continues to grow, as the United States, despite its isolationist reputation, becomes increasingly enmeshed in international regimes. As the need and opportunities for international cooperation have increased, multilateral regulatory treaties have proliferated, as have international institutions established to administer them. These institutions include a growing number of dispute resolution bodies that consider issues that overlap and intersect with the issues considered by U.S. courts.

Sanchez-Llamas $v$ Oregon $^{4}$ was an important test case for the internationalist perspective. The petitioners there, with the support of internationalist scholars, were seeking to have the Supreme Court create domestic remedies to help effectuate compliance with a multilateral treaty, and to set aside traditional state law procedures in order to implement an interpretation of the treaty that had been adopted by an international tribunal. In rejecting this effort in Sanchez-Llamas, the Court made clear that the Article III federal judicial power plays an important mediating role between the United States and the international legal system. Under the Court's approach, international law neither gives U.S. courts special powers nor limits their authority to decide cases, and U.S. courts are to consider the application of international law against the backdrop of traditional domestic remedial and procedural restrictions, even if the result is disuniformity in treaty interpretation.

While one should be cautious about reading too much into a single decision, the Court's approach to the federal judicial power in Sancbez-Llamas has potential relevance to a number of foreign

\footnotetext{
${ }^{3}$ Although hardly uniform in their approach to particular issues, scholars commonly associated with the constitutionalist approach include myself, Jack Goldsmith, Julian Ku, Eric Posner, Paul Stephan, Mark Weisburd, John Yoo, and Ernest Young.
}

${ }^{4} 126$ S Ct 2669 (2006). 
relations law issues. In this regard, Sanchez-Llamas may have broader significance than the more widely discussed decision issued by the Court a day later, Hamdan $v$ Rumsfeld, ${ }^{5}$ in which the Court held that the military commission system established by President Bush to try terrorist detainees was invalid. Hamdan may seem like a monumental decision, in that it repudiated one of the components of the Bush administration's legal strategy in the war on terrorism and seemed to give little deference to the administration's views about the scope of international law. The Court's decision there, however, ultimately rests on a particular construction of statutory provisions in the Uniform Code of Military Justice (provisions that Congress has since amended), and the Court's lack of deference may stem from facts specific to the war on terrorism, including the fact that the administration had never actually tried anyone in the military commission system that the Court was invalidating. Moreover, whereas Chief Justice Roberts wrote the majority opinion in Sancbez-Llamas, he did not even participate in Hamdan, so, to the extent that those decisions overlap, Sanchez-Llamas would seem to be a better indicator of the likely approach of the Roberts Court.

Part I of this essay briefly describes the Sanchez-Llamas decision and explains how the federal judicial power played a central role in the Court's analysis. As explained in this part, the majority viewed the federal judicial power as imposing both a restraint on the federal courts' ability to advance the international order, and a protection against the delegation of the federal courts' adjudicative functions to that order. Part II considers potential implications of these two functions of restraint and protection for various foreign relations law issues. Part III outlines several benefits of these two functions of the judicial power in light of the current conditions of the international adjudicative system.

\section{Sanchez-Llamas and the Federal Judicial Power}

This part briefly summarizes the Sanchez-Llamas decision and explains the central relevance of the federal judicial power to the decision. Next, it compares the decision with the Court's widely discussed decision a day later in Hamdan $v$ Rumsfeld. Finally, it considers whether the treaty provision at issue in Sanchez-Llamas

\footnotetext{
${ }^{5} 126$ S Ct 2749 (2006).
} 
confers judicially enforceable individual rights, an issue expressly left open by the majority.

\section{A. BACKGROUND 6}

The Vienna Convention on Consular Relations is a multilateral treaty that addresses a variety of issues concerning the exercise of consular functions and the privileges and immunities of consular officials. ${ }^{7}$ Sanchez-Llamas concerned Article 36 of this Convention, which provides that when foreign nationals from other party countries are arrested, they are to be informed without delay that they have the right to have their consulate notified of the arrest and to communicate with the consulate. ${ }^{8}$ Article 36 also states that these rights "shall be exercised in conformity with the laws and regulations of the receiving State, subject to the proviso, however, that the said laws and regulations must enable full effect to be given to the purposes for which the rights accorded under this Article are intended." The United States ratified the Vienna Convention in 1969. At the same time, it also ratified an "optional protocol" to the treaty providing that disputes between nations arising under the treaty could be heard in the International Court of Justice (ICJ) that sits in The Hague, in the Netherlands. ${ }^{10}$

State police in the United States have often failed to inform foreign nationals of their rights under Article 36 when arresting them. Before the mid-1990s, however, these violations were rarely the subject of U.S. court litigation. This changed with the Breard case. There, a Paraguayan citizen on death row in Virginia filed a federal habeas corpus action alleging that he should receive either a new trial or sentencing proceeding because he had never been advised of his right to have his consulate notified of his arrest. As the lower courts began to deny him relief, and as his execution date approached, the nation of Paraguay filed an action against the United States in the ICJ, seeking to have the Court order a

\footnotetext{
${ }^{6}$ My description here draws on Curtis A. Bradley, International Decisions: Sanchez-Llamas v Oregon, $100 \mathrm{Am} \mathrm{J} \mathrm{Intl} \mathrm{L} 882$ (2006).

' See Vienna Convention on Consular Relations, Apr 24, 1963, 21 UST 77, 596 UNTS 261.

${ }^{8}$ Id, Art 36(1)(b).

${ }^{9}$ Id, Art 36(2).

10 See Optional Protocol Concerning the Compulsory Settlement of Disputes, Apr 24, 1963, 21 UST 77, 169, 596 UNTS 487, 488.
} 
new trial for Breard. About five days before the scheduled execution, the ICJ issued a provisional order stating that the United States should "take all measures at its disposal" to ensure that Breard was not executed while the Court considered the case."

At this point, the case had also reached the U.S. Supreme Court, which declined to grant a stay of execution, concluding that Breard's Vienna Convention claim had been procedurally defaulted because he had failed to raise it in a timely manner in the state courts. ${ }^{12}$ While recognizing that it should give "respectful consideration to the interpretation of an international treaty rendered by an international court with jurisdiction to interpret such," the Court reasoned that absent "a clear and express statement to the contrary, the procedural rules of the forum State govern the implementation of the treaty in that State."13 One such procedural rule in the United States, explained the Court, is that "assertions of error in criminal proceedings must first be raised in state court in order to form the basis for relief in habeas." 14 Although the U.S. government took the position that the ICJ's provisional order was not binding, the Secretary of State at that time, Madeline Albright, wrote a letter to Virginia's governor, asking him voluntarily to stay the execution. The governor declined, however, and Breard was executed. Paraguay subsequently withdrew its case from the ICJ. ${ }^{15}$

A similar case, $\mathrm{LaGrand},{ }^{16}$ was initiated in the ICJ by Germany in 1999. LaGrand concerned two brothers of German citizenship on death row in Arizona, one of whom was executed shortly before Germany brought its case. The Court issued a provisional order directing the United States to take all measures at its disposal to stay the execution of the other brother. Once again, however, the

\footnotetext{
${ }^{" S e e}$ Vienna Convention on Consular Relations (Paraguay v United States), Provisional Measures, 1998 ICJ Rep 248, para 41 (Apr 9).

${ }^{12}$ See Breard v Greene, 523 US 371, 375 (1998). A group of international law professors filed a statement with the Court unsuccessfully urging a stay of execution. See Statement Amicus Curiae of International Law Professors, Republic of Paragtay v Gilmore, No 971390 (US Supreme Court).

${ }^{13} 523$ US at 375.

${ }^{14} \mathrm{Id}$.

${ }^{15}$ For additional discussion of the Breard litigation, see Curtis A. Bradley, Breard, Our Dualist Constitution, and the Internationalist Conception, 51 Stan L Rev 529 (1999); Agora: Breard, 92 Am J Intl L 666 (1998).

${ }^{16}$ LaGrand (Federal Republic of Germany $v$ United States), 2001 ICJ Rep 466, paras 67, 73, 77, 91 (June 27).
} 
execution was carried out on schedule. Unlike Paraguay in the Breard case, however, Germany did not abandon its case at this point, but rather pressed on for a judgment. Subsequently, in June 2001, the ICJ issued a final decision, concluding that Article 36 of the Vienna Convention confers not only state-to-state rights but also individual rights, that the United States had violated these individual rights with respect to the German brothers, and that U.S. court application of procedural default rules had prevented "full effect" from being given to the rights under Article $36 .{ }^{17}$ The ICJ also concluded that, in the future, when German nationals are sentenced to severe penalties in the United States without their Article 36 rights being respected, the United States would be obligated to provide for "review and reconsideration" of their convictions and sentences in light of the violation. ${ }^{18}$ The ICJ noted, however, that this "obligation can be carried out in various ways" and that the "choice of means must be left to the United States."19

LaGrand set the stage for the Avena case. ${ }^{20}$ In early 2003, Mexico filed an action against the United States in the ICJ on behalf of fifty-four Mexican nationals on death row throughout the United States, alleging that they had not been notified of their rights under Article 36 of the Vienna Convention. This was a particularly significant case, since it resembled a class action rather than just a challenge to a particular execution. In February 2003, the Court issued a provisional order directing the United States not to execute three of the individuals who appeared to be at greatest risk of execution in the coming months. ${ }^{21}$ This time, none of the individuals was executed while the Court considered the case.

In March 2004, the ICJ issued its judgment on the merits. The Court held that the United States had violated the Vienna Convention rights of fifty-one Mexican nationals, and that it was required to provide these Mexican nationals with review and reconsideration of their convictions and sentences as a result of having failed to notify them of their consular rights. In its opinion,

\footnotetext{
${ }^{17} \mathrm{Id}$, paras 67, 73, 77, 91.

${ }^{18}$ Id, para 125.

${ }^{19}$ Id.

${ }^{20}$ Case Concerning Avena and Other Mexican Nationals (Mexico v United States), 2004 ICJ No 128 (Judgment Mar 31 ).

${ }^{21}$ See Case Concerning Avena and Otber Mexican Nationals (Mexico v United States), Provisional Measures, 2003 ICJ 128 (Feb 5).
} 
the Court reasoned that Article 36 confers individual rights, and that the proper remedy for a violation of these rights is "review and reconsideration of these nationals' cases by the United States courts . . . with a view to ascertaining whether in each case the violation of Article 36 . . . caused actual prejudice to the defendant in the process of administration of criminal justice."22 The ICJ further suggested that procedural default rules should not be applied to bar this review and reconsideration because the application of such rules would prevent full effect from being given to the rights. $^{23}$

After the Avena decision, the Executive Branch took the position that the ICJ had erred in its construction of the Convention. In a case involving one of the Mexican nationals covered by Avenain which the Supreme Court granted a writ of certiorari but subsequently dismissed the writ as improvidently granted ${ }^{24}$ - the Executive Branch filed a brief arguing, among other things, that Article 36 did not confer any private, judicially enforceable rights, that the article did not preclude application of procedural default rules, and that the Avena decision was not directly enforceable in U.S. courts. ${ }^{25}$ The brief informed the Supreme Court, however, that President Bush had written a memorandum to the U.S. Attorney General stating that the United States, "in accordance with general principles of comity," would discharge its obligations under Avena by having its state courts provide review and reconsideration in the fifty-one cases covered by Avena, and that this memorandum would, it was argued, override state procedural default rules. ${ }^{26}$ About a week later, the U.S. Secretary of State sent a letter to the UN Secretary-General stating that the United States was withdrawing from the optional protocol that gives the ICJ jurisdiction over Vienna Convention disputes. ${ }^{27}$

\footnotetext{
${ }^{22}$ See 2004 ICJ No 128, at para 121.

${ }^{23} \mathrm{Id}$, para 113.

${ }^{24}$ See Medellin v Dretke, 544 US 660 (2005).

${ }^{25}$ See Brief for the United States as Amicus Curiae Supporting Respondent, at 9, Medellin $v$ Dretke, No 04-5928 (US Supreme Court, Feb 2005).

${ }^{26}$ See id at 38-48; Charles Lane, U.S. Quits Pact Used in Capital Cases, Wash Post, Mar 10,2005 , at A01.

27 See Memorandum for the Attorney General, "Compliance with the Decision of the International Court of Justice in Avena" (Feb 28, 2005), at http://brownwelsh.com/Archive/ 2005-03-10_Avena_compliance.pdf.
} 
B. SANCHEZ-LLAMAS AND THE FEDERAL JUDICIAL POWER

Sanchez-Llamas involved two consolidated state cases, one from Oregon and one from Virginia. ${ }^{28}$ In each case, state police had failed to advise a foreign citizen of his rights under Article 36 of the Vienna Convention. In the Oregon case, a Mexican citizen was seeking suppression of incriminating statements as a remedy for the treaty violation, and in the Virginia case a Honduran citizen was seeking to overcome state rules of procedural default that would otherwise prevent him from raising the treaty violation for the first time in state postconviction proceedings. The Supreme Court granted certiorari on three questions: "(1) whether Article 36 of the Vienna Convention grants rights that may be invoked by individuals in a judicial proceeding; (2) whether suppression of evidence is a proper remedy for a violation of Article 36; and (3) whether an Article 36 claim may be deemed forfeited under state procedural rules because a defendant failed to raise the claim at trial." 29

In an opinion authored by Chief Justice Roberts, a majority of the Court rejected the claims of both petitioners. The Court did not take a position on whether Article 36 confers judicially enforceable individual rights. The Court reasoned that, even if Article 36 does confer such rights, suppression of evidence is not an appropriate remedy for violations of that article, and that the article does not override state rules of procedural default.

The Court emphasized the federal judicial power in both its analysis of the suppression issue and its analysis of the procedural default issue. In concluding that there was no suppression of evidence remedy for violations of Article 36, the Court rejected the argument that it could use its remedial authority to promote state court compliance with Article 36. The Court explained that "our authority to create a judicial remedy applicable in state court must lie, if anywhere, in the treaty itself." 30 Imposing a remedy not provided for by the Convention, the Court noted, would be "enlarging the obligations of the United States under the Vienna Convention," which would be "entirely inconsistent with the ju-

\footnotetext{
${ }^{28}$ See 126 S Ct 2669 (2006).

${ }^{29}$ Id at 2677.

${ }^{30}$ Id at 2679 .
} 
dicial function." 31 The Court concluded that, "where a treaty does not provide a particular remedy, either expressly or implicitly, it is not for the federal courts to impose one on the States through lawmaking of their own." 32 In other words, regardless of whether fashioning a suppression remedy would promote U.S. compliance with Article 36, limitations on the judicial power meant that this was not an appropriate task for the federal courts.

In concluding that Article 36 did not override state rules of procedural default, despite the ICJ's view that it did, the Court similarly focused on the judicial power-this time as something to be protected rather than kept in check. The Court rejected the argument, advanced by a group of international law professors in an amicus curiae brief, ${ }^{33}$ that the Court was obligated to accept as "authoritative" the ICJ's interpretation of the Vienna Convention. The Court explained that, although the ICJ's interpretation deserves "respectful consideration," when treaties are being applied as federal law, the ultimate authority to interpret them must rest with the domestic U.S. court system, not an international tribunal. Citing Marbury v Madison, the Court stated that "[i]f treaties are to be given effect as federal law under our legal system, determining their meaning as a matter of federal law 'is emphatically the province and duty of the judicial department,' headed by 'one Supreme Court' established by the Constitution." ${ }^{34}$ Invoking stare decisis, the Court also reasoned that its "respectful consideration" of the ICJ's views "does not compel us to reconsider our understanding of the Convention in Breard." 35

In sum, the Court's conception of the federal judicial power is that it operates both as a limitation on the federal courts' ability to participate in the international order, and also as a protection of the federal courts from that order. In particular, the Court appeared to deny itself a foreign affairs lawmaking power, even for the purpose of promoting treaty compliance, while at the same time suggesting that there are limitations on the extent to which

${ }^{31}$ Id.

${ }^{32}$ Id at 2680 .

${ }^{33}$ See Brief of International Court of Justice Experts as Amici Curiae in Support of Petitioners, at 2-3, 20, 25 and n 41, Sanchez-Llamas v Oregon, Nos 04-10566, 05-51 (US Supreme Court).

${ }^{34} 126 \mathrm{~S} \mathrm{Ct}$ at 2684.

${ }^{35}$ Id at 2683. 
the federal judicial power may be diluted through U.S. participation in international adjudication.

Justice Breyer issued a dissent, joined by Justices Stevens and Souter, and joined in part by Justice Ginsburg. ${ }^{36}$ These four Justices reasoned that Article 36 provides an individual right that can be invoked by criminal defendants in domestic proceedings. They also argued that sometimes suppression is an appropriate remedy for violations of Article 36, and that sometimes state procedural default rules must be set aside. Three of these Justices (but not Justice Ginsburg) thought it appropriate to remand for a determination of whether those remedies should be applied to these particular cases. Although these Justices stated that they would assume that the ICJ's interpretation was not binding on the Court, they suggested that it should be given more weight than it was given by the majority, in the interest of promoting uniformity of treaty interpretation. ${ }^{37}$

\section{COMPARISON WITH HAMDAN}

In public discussions, the Sanchez-Llamas decision was overshadowed by the Court's decision a day later in Hamdan v Rumsfeld. ${ }^{38}$ In Hamdan, the Court invalidated the military commission system that President Bush had established after the September 11 attacks to try terrorist "enemy combatants." The Court based its decision, in part, on purported inconsistencies between the military commission system and a treaty provision-Common Article 3 of the 1949 Geneva Conventions. ${ }^{39}$

The Court's reliance on a treaty provision to invalidate Executive action in Hamdan might appear to be in tension with the limited judicial role for enforcing treaties suggested in SanchezLlamas. However, the Court in Hamdan, and Justice Kennedy in his concurrence, emphasized that the treaty provision there was

\footnotetext{
${ }^{36}$ See id at 2690-2709 (Breyer, J, dissenting).

${ }^{37}$ See id at 2700 (Breyer, J, dissenting). In what can only be described as a creative reading of the Avena decision, these Justices also suggested that a hearing in which procedural default rules were applied might itself satisfy the ICJ's requirement of "review and reconsideration," and that it would be consistent with Avena for states to apply procedural default rules as long as the defendant could pursue an ineffective assistance of counsel claim based on the failure of his lawyer to raise the Article 36 claim in time. See id at 2698, 2702-03 (Breyer, J, dissenting).
}

${ }^{38}$ See 126 S Ct 2749 (2006).

${ }^{39}$ See id at 2793-97. 
being applied because Congress had implicitly directed its domestic application. The Court explained, for example, that "regardless of the nature of the rights conferred [by Common Article $3]$. . . they are, as the Government does not dispute, part of the law of war," and "compliance with the law of war is the condition upon which the authority [for military commissions] set forth in [the Uniform Code of Military Justice] is granted." ${ }^{40}$ The Court did not conceive of Hamdan, therefore, as a case in which courts were being asked to act, independently of the political branches, in providing remedies for breaches of international law. Nor, unlike in Sanchez-Llamas, was the Court being asked to defer to an international body's construction of the treaty. Furthermore, both decisions considered international law against the backdrop of traditional U.S. procedures. Whereas in Sanchez-Llamas these procedures included procedural default and stare decisis, in Hamdan they concerned the procedures that had traditionally been used for military courts-martial. ${ }^{41}$ Even at the more general level of respect for international law, Sanchez-Llamas and Hamdan are not inconsistent. Whatever one may think of the Court's ultimate conclusions in Sanchez-Llamas, it is difficult to dispute that the Court took the international law arguments seriously. The Court carefully parsed the language of Article 36, examined its drafting history, and considered how other nations had been enforcing it. Moreover, in considering the proper remedy and the effect of state procedural rules, the Court treated the Article 36 violation in much the same way that it would treat violations of other federal law. The fact that it perceived structural and procedural restraints on its ability to grant the relief requested does not show disrespect for international law. As the Court explained, "[i]t is no slight to the Convention to deny petitioners' claims under the same principles we would apply to an Act of Congress, or to the Constitution itself." ${ }^{\prime 2}$

There is one way, however, in which the two decisions do seem inconsistent. Traditionally, the Supreme Court has given substantial deference to the Executive Branch's interpretations of treaties, stating, for example, that these interpretations are entitled to

\footnotetext{
${ }^{40}$ Id at 2794; see also id at 2774, 2786; id at 2802 (Kennedy, J, concurring).

${ }^{41} \mathrm{See}$, e.g., id at 2788 ("[T]he procedures governing trials by military commission historically have been the same as those governing courts-martial.").

${ }^{42}$ Id at 2688.
} 
"great weight." 43 The majority in Sanchez-Llamas cited and quoted with approval from this line of authority and ultimately agreed with the Executive Branch's views regarding the implications of Article 36 for suppression of evidence and procedural default. In Hamdan, however, the Court interpreted Common Article 3 of the Geneva Conventions to apply to a conflict between the United States and a nonstate terrorist organization, and it did not appear to give much deference to a contrary interpretation by the Executive Branch. ${ }^{44}$ It should be noted, however, that Chief Justice Roberts did not participate in Hamdan, so Sancbez-Llamas is probably a better indicator than Hamdan of how the Roberts Court is likely to approach treaty cases. ${ }^{45}$ Moreover, the Court's lack of deference to the Executive Branch in Hamdan might have stemmed from factors specific to U.S. policy at Guantánamo Bay-such as the international public relations difficulties engendered by the U.S. detention facility and the long delay in initiating any military commission trials there-and may not be indicative of more general views relating to treaty deference.

\section{PRIVATE ENFORCEMENT OF ARTICLE 36}

As noted above, four Justices in Sancbez-Llamas - the three dissenting Justices, and Justice Ginsburg-made clear that they believed that Article 36 confers judicially enforceable private rights. The majority did not take a position on this issue, stating that it would "assume, without deciding, that Article 36 does grant [the petitioners] such rights." ${ }^{46}$ This issue presumably will arise in other litigation-for example, on direct review where there is no procedural default bar, and where remedies other than suppression of evidence are sought (such as a new sentencing hearing). Prior to Sanchez-Llamas, the lower courts were divided on the issue. ${ }^{47}$

\footnotetext{
${ }^{43}$ See, e.g., United States v Stuart, 489 US 353, 369 (1989); Sumitomo Shoji America, Inc. $v$ Avagliano, 457 US 176, 184-85 (1982); Kolovrat v Oregon, 366 US 187, 194 (1961).

${ }^{44}$ See $126 \mathrm{~S} \mathrm{Ct}$ at $2795-96$.

${ }^{45}$ Roberts recused himself in Hamdan because he had participated in the decision under review. In that decision, Roberts had joined in an opinion holding, among other things, that the Geneva Conventions do not confer judicially enforceable private rights. See Hamdan v Rumsfeld, 415 F3d 33, 38-40 (DC Cir 2005).

${ }^{40} 126 \mathrm{~S} \mathrm{Ct}$ at $2677-78$.

${ }^{47}$ Compare fogi $v$ Voges, 425 F3d 367 (7th Cir 2005) (concluding that Article 36 confers judicially enforceable private rights), with United States $v$ fimenez-Nava, 243 F3d 192, 195-98 (5th Cir 2001) (concluding that Article 36 does not confer judicially enforceable
} 
Textually, this issue appears to be a closer one than the suppression and procedural default issues decided in Sanchez-Llamas. Article 36 imposes mandatory obligations on arresting authorities and specifically refers to "rights." ${ }^{48}$ Moreover, some of the functional and constitutional concerns associated with implying a suppression remedy or an override of procedural default rules do not apply to this issue, since it is not uncommon for federal statutes to confer individual rights, including rights enforceable in state courts. On the other hand, there is no mention of judicial enforcement in the Vienna Convention, and the preamble to the Convention states that the purpose of the privileges and immunities set forth in the Convention "is not to benefit individuals but to ensure the efficient performance of functions by consular posts on behalf of their respective States." Although the ICJ has concluded that Article 36 does confer individual rights, its reasoning on this issue, like the procedural default issue, is presumably entitled only to "respectful consideration." Moreover, it is not entirely clear that this is a question of treaty interpretation, as opposed to a question of U.S. law governing the circumstances under which a law should be viewed as allowing for private enforcement.

This issue of private treaty enforcement implicates broader debates in the literature over the extent to which treaties should be viewed like federal statutes. On the one hand, the Supremacy Clause of the Constitution refers to treaties, along with federal statutes and the Constitution, as the "supreme Law of the Land." On the other hand, treaties, unlike statutes, are international contracts, and by definition concern U.S. foreign relations. As a result, it is arguable that they should be less amenable than statutes to direct judicial enforcement. This may partially explain the special doctrine of "non-self-execution" that has existed since the early 1800 s, pursuant to which some treaties are viewed as judicially unenforceable until they are implemented by Congress. ${ }^{50}$ As treaties have grown in number and breadth, this concept of non-self-

private rights). Many courts prior to Sanchez-Llamas had avoided deciding this question, instead holding simply that Article 36 did not confer the particular remedies being sought in those cases (such as suppression of evidence).

${ }^{48}$ See Vienna Convention, Art 36(1)(b) ("The said authorities shall inform the person concerned without delay of his rights under this sub-paragraph.").

${ }^{49}$ US Const, Art VI.

${ }^{50}$ See Foster $v$ Neilson, 27 US (2 Pet) 253, 314 (1829). 
execution has also grown, to the dismay of internationalist commentators who view the doctrine as in tension with the Supremacy Clause and as undermining U.S. compliance with international law. Constitutionalist scholars, by contrast, tend to see the doctrine as a means of fostering democratic deliberation in the implementation of modern treaties. ${ }^{51}$

The term "self execution" has in turn become a highly confusing concept, in part because it is often used to mean different propositions. ${ }^{52}$ It is sometimes used simply to suggest the lack of a need for implementing legislation. At other times, it is used to suggest judicial enforceability. In still other instances, it may denote the existence of a private cause of action. Litigants, not surprisingly, seek to use this ambiguity to their advantage. In SancbezLlamas, for example, the petitioners and their amicus supporters pointed out that when the Vienna Convention was originally submitted to the Senate, the State Department had testified that the Convention was "entirely self-executive and does not require any implementing or complementing legislation." "53 This statement, however, was probably intended simply to signify that the treaty did not need implementing legislation to become operative, not necessarily to suggest that the treaty would be privately enforceable in domestic courts.

The position of the current administration is that treaties are presumptively not enforceable by private parties. In its amicus brief in Sanchez-Llamas, the Executive Branch maintained that "[i]t is a long-established presumption that treaties and other international agreements do not create judicially enforceable individual rights." ${ }^{54}$ It is far from clear, however, that there is any such general presumption, although it may be true that of the vast number of treaties today, most do not confer judicially enforceable individual rights. The Executive relies heavily on the Head Money Cases for

\footnotetext{
${ }^{51}$ See, e.g., Curtis A. Bradley and Jack L. Goldsmith, Treaties, Human Rights, and Conditional Consent, 149 U Pa L Rev 399, 457-59 (2000).

${ }^{52}$ See Carlos Manuel Vazquez, The Four Doctrines of Self-Executing Treaties, 89 Am J Intl L 695 (1995).

${ }^{53}$ See Brief for Petitioner Mario A. Bustillo, at 20, Bustillo v fobnson, No 05-51 (US Supreme Court, Dec 2005); Brief for Petitioner Moises Sanchez-Llamas, at 13, SancbezLlamas v Oregon, No 04-10566 (US Supreme Court, Dec 22, 2005); Brief of International Court of Justice Experts, at 20 (cited in note 33).

${ }^{54}$ Brief for the United States as Amicus Curiae Supporting Respondents, at 11, Bustillo $v$ Jobnson, Nos 05-51, 04-10566 (US Supreme Court, Jan 2006).
} 
the purported presumption, but that decision (which stands for the different proposition that Congress has the authority to override treaties for purposes of U.S. law) contains language that cuts both ways. While noting that "[a] treaty is primarily a compact between independent nations" that "depends for the enforcement of its provisions on the interest and honor of the governments which are parties to it," the Court also observed that "a treaty may also contain provisions which confer certain rights upon the citizens or subjects of one of the nations residing in the territorial limits of the other, which partake of the nature of municipal law, and which are capable of enforcement as between private parties in the courts of the country." 55 Moreover, in some contexts, such as extradition and alien property rights, treaties (particularly bilateral treaties) have long been treated as conferring judicially enforceable private rights. ${ }^{56}$

The debate over whether treaties should be viewed like statutes is complicated even more by disagreements over the proper baseline. Whereas the Executive Branch resists the analogy to statutes out of concern that it would expand judicial enforcement of treaties, that may depend on the type of statute covered by the analogy. If modern treaties are like regulatory statutes, it is arguable that the presumption would still be against private enforcement. ${ }^{57}$ Many important regulatory statutes, after all, have been found not to confer judicially enforceable individual rights. ${ }^{58}$ Viewed this way, it is easier to see why the mere fact that treaties are listed in the Supremacy Clause is not dispositive of the issue of private judicial enforcement.

There are suggestions in Sanchez-Llamas that the majority might not be receptive to allowing private judicial enforcement of Article 36. The majority noted that "diplomatic avenues" are "the primary means of enforcing the Convention," and it stated that there "is reason to doubt" that Article 36 requires a judicial remedy. ${ }^{59}$ The

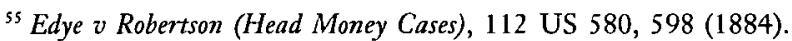

${ }^{\text {s6 }}$ See, e.g., Clark v Allen, 331 US 503 (1947); Asakura v Seattle, 265 US 332 (1924); United States v Rauscher, 119 US 407 (1886).

${ }^{57}$ See Paul B. Stephan, Private Remedies for Treaty Violations after Sanchez-Llamas, 11 Lewis and Clark L Rev 65 (2007).

${ }^{58}$ See, e.g., Gonzaga University v Doe, 536 US 273 (2002) (Family Educational Rights and Privacy Act of 1974); Alexander v Sandoval, 532 US 275 (2001) (Section 602 of Civil Rights Act of 1964).
}

${ }^{59} 126 \mathrm{~S} \mathrm{Ct}$ at $2680,2682$. 
majority also made clear that it would give some deference to the Executive Branch's construction of Article 36, and the Executive Branch has for a number of years taken the position that this article does not confer judicially enforceable private rights. ${ }^{60}$ As with many issues that the Roberts Court will address, Justice Kennedy's views are likely to be critical here. His vote and concurrence in Hamdan might suggest that he is receptive to private judicial enforcement of treaties. As noted above, however, Justice Kennedy made clear that the Court was enforcing the treaty provision in Hamdan because of an underlying statutory incorporation, ${ }^{61}$ whereas there has been no statutory incorporation of Article 36 of the Vienna Convention.

\section{Potential Implications for U.S. Foreign Relations Law}

This part considers potential implications for U.S. foreign relations law of both the restrictive and protective roles for the judicial power envisioned in Sancbez-Llamas. The part concludes by assessing the implications of these functions for the enforceability of President Bush's 2005 memorandum, in which he stated that the United States would comply with the ICJ's decision in Avena by having state courts give effect to the decision in the fiftyone cases covered by the decision.

\section{A. THE JUDICIAL POWER AS LIMITATION}

The limiting function of the judicial power envisioned in Sanchez-Llamas is potentially relevant to at least four issues in U.S. foreign relations law: judicial federalism, the viability of dormant foreign relations preemption, the domestic application of customary international law, and the scope of the Charming Betsy canon of construction. The organizing theme for these issues concerns the default role of the courts. Under the internationalist approach, U.S. courts are to act independently from the political branches in promoting U.S. internationalism, subject to post hoc political branch correction. Under the constitutionalist approach as reflected in Sanchez-Llamas, by contrast, decisions about U.S. internationalism are to be made in the first instance by the political

\footnotetext{
${ }^{60}$ See United States v Li, 206 F3d 56, 63 (1st Cir 2000) (quoting view of State Department that the Vienna Convention is not a treaty "establishing rights of individuals").

${ }^{61}$ See note 40 .
} 
branches, through processes designed to protect structural constitutional values.

1. Fudicial federalism. The conventional wisdom among internationalist scholars is that federalism is irrelevant to U.S. foreign relations law. Professor Louis Henkin reflects this view in stating that, "as regards U.S. foreign relations, the states 'do not exist."'62 There is Supreme Court dicta supporting this view, particularly in cases from the $1930 \mathrm{~s}$ and $1940 \mathrm{~s}^{63}$

This conventional wisdom has never mapped well onto reality. States and localities routinely engage in a host of actions that can affect foreign relations, and almost none of it is subject to federal preemption. ${ }^{64}$ They arrest and try foreign nationals, decide whether to apply foreign law and enforce foreign judgments, and form a variety of commercial and other relationships with other countries. Moreover, the federal political branches have long considered federalism in deciding which treaties to ratify, in attaching various reservations to U.S. ratification of treaties, and in crafting legislation to implement treaties. ${ }^{65}$ And, whether it is claimed opportunistically or with genuine conviction, the political branches have often suggested that federalism places constitutional restrictions on their activities in foreign relations. ${ }^{66}$ This has been true even in the Vienna Convention litigation: In the Breard litigation before the Supreme Court, the Executive Branch maintained that "our federal system imposes limits on the federal government's ability to interfere with the criminal justice system of the States." ${ }^{\text {"I }}$ In arguing the LaGrand case before the ICJ, the Executive Branch stated that "[f]ederal Government officials do not have legal power to stop peremptorily the enforce-

${ }^{62}$ Louis Henkin, Foreign Affairs and the United States Constitution 150 (2d ed 1996).

${ }^{63}$ See, e.g., United States $v$ Pink, 315 US 203, 233 (1942) ("[P]ower over external affairs is not shared by the States; it is vested in the national government exclusively."); United States v Belmont, 301 US 324, 331 (1937) ("[I]n respect of our foreign relations generally, state lines disappear. As to such purpose . . . the State does not exist."). Both of these decisions involved the preemption of state law through a "sole executive agreement"that is, an international agreement concluded with another country solely by the President.

${ }^{64}$ See generally Dennis J. Palumbo, The States and American Foreign Relations (1960); Jack L. Goldsmith, Federal Courts, Foreign Affairs, and Federalism, 83 Va L Rev 1617 (1997).

${ }^{65}$ See Curtis A. Bradley and Jack L. Goldsmith, The Abiding Relevance of Federalism to U.S. Foreign Relations, 92 Am J Intl L 675 (1998); Duncan B. Hollis, Executive Federalism: Forging New Federalist Constraints on the Treaty Power, 79 S Cal L Rev 1327 (2006).

${ }^{66}$ See Curtis A. Bradley, The Treaty Power and American Federalism, Part II, 99 Mich L Rev 98, 131-32 (2000) (providing examples).

${ }^{67}$ Brief for the United States as Amicus Curiae at 51, Breard v Greene, Nos 97-8214, 97-1390 (US Supreme Court). 
ment of a criminal sentence by the state of Arizona." 68

Recent academic debates on this topic have primarily concerned the extent to which federalism restricts the authority of the federal political branches. One issue that has generated particular controversy is whether the treaty power is subject to federalism restrictions. The Supreme Court's 1920 decision in Missouri v Holland holds that the treaty power is not subject to the federalism limitations applicable to legislation. ${ }^{69}$ Academic debates have focused on the continued vitality of Holland in light of the Supreme Court's renewed commitment to federalism in the domestic arena, and the expansion of treatymaking to encompass a variety of matters that were traditionally of state and local concern. ${ }^{70}$ A number of intermediate positions have arisen in the debate, including the proposition that "anti-commandeering" and state sovereign immunity limitations apply to the treaty power even if that power is not subject to the Article I limitations applicable to legislation, ${ }^{71}$ and the proposition that federalism restricts executive agreements but not Article II treaties. ${ }^{72}$

Sanchez-Llamas reminds us that federalism can be relevant in a different way to foreign relations law-not as a limitation on the political branches, but rather as a limitation on the role of the courts. Federalism values were directly implicated in Sanchez-Llamas. The two consolidated cases arose from state courts, and they concerned issues of criminal law and procedure, core areas of state interest. ${ }^{73}$ The Supreme Court did not question the authority of the political

\footnotetext{
${ }^{68}$ Counter-Memorial Submitted by the United States of America, LaGrand Case, para 124 (Mar 27, 2000), at http://www.icj-cij.org/icjwww/idocket/igus/igusframe.htm.

${ }^{69}$ See Missouri v Holland, 252 US 416 (1920).

${ }^{70}$ See Curtis A. Bradley, The Treaty Power and American Federalism, 97 Mich L Rev 390 (1998); David M. Golove, Treaty-Making and the Nation: The Historical Foundations of the Nationalist Conception of the Treaty Power, 98 Mich L Rev 1075 (2000); Bradley, 99 Mich L Rev (cited in note 66); Nicholas Quinn Rosenkranz, Executing the Treaty Power, 118 Harv L Rev 1867 (2005).

${ }^{7}$ See, e.g., Carlos Manuel Vazquez, Treaties and the Eleventh Amendment, 42 Va J Intl L 713 (2002); Carlos Manuel Vazquez, Breard, Printz, and the Treaty Power, 70 U Colo L Rev 1317 (1999).

${ }^{72}$ See, e.g., David Sloss, International Agreements and the Political Safeguards of Federalism, 55 Stan L Rev 1693 (2003).

${ }^{73}$ Cf. United States v Morrison, 529 US 598, 617 (2000) ("The regulation and punishment of intrastate violence that is not directed at the instrumentalities, channels, or goods involved in interstate commerce has always been the province of the States."); United States $v$ Lopez, 514 US 549, 561 n 3 (1995) ("Under our federal system, the 'States possess primary authority for defining and enforcing the criminal law.") (citations omitted).
} 
branches to displace state law through the treaty power, noting that "where a treaty provides for a particular judicial remedy, there is no issue of intruding on the constitutional prerogatives of the States." In rejecting the petitioners' arguments, however, the Court emphasized the relevance of federalism to the scope of the judicial power. The Court disclaimed any supervisory authority over state court proceedings, even for the purpose of effectuating compliance with international law. ${ }^{75}$ The Court also stated that, "where a treaty does not provide a particular remedy . . . it is not for the federal courts to impose one on the States through lawmaking of their own." J6 Justice Ginsburg similarly emphasized judicial federalism in her concurrence. Noting that federal courts are allowed to apply procedural default rules to bar treaty claims, including claims under the Vienna Convention, Justice Ginsburg expressed the view that:

it would be unseemly, to say the least, for this Court to command state courts to relax their identical, or even less stringent procedural default rules, while federal courts operate without constraint in this regard. That state of affairs, surely productive of friction in our federal system, should be resisted if there is a plausible choice, i.e., if a reasonable interpretation of the federal statute and international accord would avoid the conflict. ${ }^{77}$

There is an often overlooked connection between this sort of judicial federalism and arguments for not enforcing federalism limits against the political branches. The most frequently cited argument for why the courts should not enforce federalism restraints is that state interests are adequately addressed in the political process. ${ }^{78}$ To the extent that this argument has merit (and its empirical validity is contested), it may be particularly strong with respect to Article II treaties, which require the advice and consent of two-thirds of

\footnotetext{
${ }^{74} 126 \mathrm{~S} \mathrm{Ct}$ at 2680.

${ }^{75}$ See id at 2679.

${ }^{76}$ Id at 2680.

${ }^{77}$ Id at 2689 (Ginsburg, J, concurring).

${ }^{78}$ See generally Jesse H. Choper, Fudicial Review and the National Political Process (1980); Herbert Wechsler, The Political Safeguards of Federalism: The Role of the States in the Composition and Selection of the National Government, 54 Colum L Rev 543 (1954). See also Garcia v San Antonio Metropolitan Transit Autbority, 469 US 528, 550-53 (1985).
} 
the Senate. ${ }^{79}$ These process protections, however, do not apply to actions by the federal judiciary. By subjecting the judicial power to federalism limitations, courts help ensure that the political process protections for federalism actually operate. ${ }^{80}$

2. Viability of dormant foreign relations preemption. Judicial federalism is in turn relevant to a separate foreign relations law issue, which is whether courts should subject state and local laws to "dormant" foreign relations preemption. The Constitution prohibits the states from engaging in certain foreign relations activities, such as treaty-making, and it grants the federal government broad authority to preempt other state foreign affairs activities. This constitutional structure might naturally be read to suggest that when states are not engaging in activities expressly prohibited by the Constitution, they are subject to preemption only when the political branches actually exercise their preemptive authority. ${ }^{81}$ Some commentators contend, however, that the federal courts should enforce a "dormant" preemption to ensure that states do not unduly intrude on the ability of the United States to speak with "one voice." 82

The Supreme Court has applied dormant foreign relations preemption only once, in the Cold War decision, Zscbernig v Miller. ${ }^{83}$ The issue there was the validity of an Oregon inheritance statute that effectively disallowed residents of communist countries from inheriting personal property from Oregonian decedents. Despite concluding that no treaty or federal statute preempted the state law, the Court held that the law was invalid because of its "direct impact upon foreign relations." 84 The Court reached this conclusion even though the Executive Branch had informed the Court that the

${ }^{79}$ But cf. Bradley, 97 Mich L Rev at 442-43 (cited in note 70) (questioning the extent to which state interests are protected in light of the Seventeenth Amendment, the rise of executive agreements, the opaque nature of the treaty-making process, and the vagueness of many of the treaty provisions that pose federalism issues).

${ }^{80}$ See Bradford R. Clark, Separation of Powers as a Safeguard of Federalism, 80 Tex L Rev 327 (2001).

${ }^{81}$ For an argument along these lines, see Goldsmith, 83 Va L Rev (cited in note 64).

${ }^{82}$ See, e.g., Henkin, Foreign Affairs and the United States Constitution at 139 (cited in note 62); Brannon P. Denning and Jack H. McCall, Jr., The Constitutionality of State and Local "Sanctions" Against Foreign Countries: Affairs of State, States' Affairs, or a Sorry State of Affairs? 26 Hastings Const L Q 307, 349-50 (1999); John Norton Moore, Federalism and Foreign Relations, 1965 Duke L J 248, 275-76.

${ }^{83} 389$ US 429 (1968).

${ }^{84}$ Id at 441 . 
Oregon statute did not unduly interfere with foreign relations. ${ }^{85}$ The Court in Zschernig thus envisioned itself as having an independent role in policing, and invalidating, state foreign affairs activities.

Some commentators thought that a 1994 decision, Barclays Bank $v$ Franchise Tax Board, ${ }^{86}$ might have spelled the end for dormant foreign relations preemption. There, the Court held that a California system for taxing multinational corporations, which had generated substantial foreign protest and Executive Branch complaint, did not unconstitutionally interfere with the ability of the national government to speak with "one voice." The Court explained that "[t]he Constitution does 'not make the judiciary the overseer of our government," and that, as a result, the Court would "leave it to Congress-whose voice, in this area, is the Nation's-to evaluate whether the national interest is best served by tax uniformity, or state autonomy." ${ }^{7}$

In subsequent decisions, the Supreme Court has latched onto a different doctrine- “obstacle" preemption-to displace state foreign relations activities. ${ }^{88}$ In doing so, it has shown less tolerance for such activities than one might have predicted after Barclays Bank. Nevertheless, the Court has at the same time gone out of its way not to endorse Zschernig. In American Insurance Association v Garamendi, for example, the majority referred to Zschernig only in the passive voice, noting that "reliance [by the petitioners] is placed on our decision in Zschernig v. Miller," and it declined to rest its finding of preemption on the decision. ${ }^{89}$ Justice Ginsburg's dissent, which was joined by three other Justices, treated Zschernig with even less enthusiasm, noting that, "[w]e have not relied on Zscbernig since it was decided, and I would not resurrect that decision here." $" 90$

The limiting function of the judicial power reflected in Sanchez-

${ }^{85}$ See id at 460 (Harlan, J, concurring).

${ }^{86} 512$ US 298 (1994).

${ }^{87}$ Id at 330-31 (citations omitted).

${ }^{88}$ See American Insurance Association v Garamendi, 539 US 396 (2003); Crosby v National Foreign Trade Council, 530 US 363 (2000).

${ }^{89} 539$ US 396, 417 (2003). In a cryptic footnote, the majority suggested that dormant preemption might be appropriate only when a state "take[s] a position on a matter of foreign policy with no serious claim to be addressing a traditional state responsibility." Id at $420 \mathrm{n} 11$. Under that approach, Zschernig was wrongly decided, since Oregon in that case was legislating in the area of inheritance, a traditional state responsibility.

${ }^{90} 539$ US at 439 (Ginsburg, J, dissenting). 
Llamas suggests that the Roberts Court may be even less enthusiastic than the Rehnquist Court about dormant foreign relations preemption. Contrary to the approach in Zschernig, the Court in Sanchez-Llamas insisted that the "judicial function" did not give it a supervisory role over state courts, even in cases affecting foreign relations, and the Court at least suggested that federal preemption of state law must be grounded in law that has been approved by the federal political branches.

3. Domestic application of customary international law. One of the most controversial debates in foreign relations law in the last decade has concerned the domestic status of customary international law. Referred to historically as part of the "law of nations," customary international law is the law of the international community that "results from a general and consistent practice of states followed by them from a sense of legal obligation." ${ }^{\prime 1}$ Despite occasional claims to the contrary, there now appears to be widespread agreement that, prior to Erie v Tompkins, customary international law had the status in the United States of general common law. That is, state and federal courts felt free to apply it in appropriate cases, but they did not view it as supreme federal law that would either preempt state law or provide a basis for federal question jurisdiction. This approach fits well with the text of the Supremacy Clause, which lists treaties, but not the law of nations, as preemptive federal law.

The post-Erie status of customary international law has generated significant disagreement among academic commentators. Internationalist commentators claim that customary international law automatically has the status today of federal common law and thereby preempts state law, serves as a source of federal question jurisdiction, and potentially even overrides Executive Branch authority. ${ }^{92}$ Constitutionalist commentators, by contrast, have argued that customary international law has the status of federal common law only when the political branches have authorized courts to incorporate it as such. ${ }^{93}$ As with many foreign relations law debates, intermediate positions have also arisen, with some commentators claiming that

\footnotetext{
${ }^{91}$ Restatement (Third) of the Foreign Relations Law of the United States $\$ 102(1)$ (1987).

${ }^{92}$ See, e.g., Lea Brilmayer, Federalism, State Authority, and the Preemptive Power of International Law, 1994 Supreme Court Review 295; Louis Henkin, International Law as Law in the United States, 82 Mich L Rev 1555 (1984); Harold Hongju Koh, Is International Law Really State Law? 110 Harv L Rev 1824 (1997).

${ }^{93}$ See, e.g., Curtis A. Bradley and Jack L. Goldsmith, Customary International Law as Federal Common Law: A Critique of the Modern Position, 110 Harv L Rev 815 (1997).
} 
customary international law might be federal law only for jurisdictional purposes, ${ }^{94}$ or that customary international law might still operate as general common law despite the holding in Erie that "there is no more federal general common law.".5

Customary international law comes up frequently in human rights litigation brought under the Alien Tort Statute. This statute, first enacted in 1789 as part of the Judiciary Act, provides simply that the federal district courts "shall have original jurisdiction of any civil action by an alien for a tort only, committed in violation of the law of nations or a treaty of the United States." "96 Ever since the Second Circuit's 1980 decision in Filartiga $v$ Pena-Irala, ${ }^{97}$ the statute has become a fount of international human rights litigation-that is, suits by aliens against other aliens for human rights abuses committed in other countries. Essentially all of these cases have involved alleged violations of the "law of nations," or customary international law, rather than treaties, because the United States has either not ratified the relevant human rights treaties or has ratified them subject to non-self-execution declarations that render them unenforceable in U.S. courts.

In allowing this litigation, the Filartiga decision and its progeny embraced an internationalist conception of the role of the federal courts. In explaining how Article III jurisdictional requirements were satisfied in Filartiga despite the lack of a treaty or statutory cause of action and the lack of diversity jurisdiction, the court there invoked the judiciary's federal common law powers and cited to " $[\mathrm{t}]$ he Framers' overarching concern that control over international affairs be vested in the new national government to safeguard the standing of the United States among the nations of the world." 98 The court concluded by describing its approach as "a small but important step in the fulfillment of the ageless dream to free all

\footnotetext{
${ }^{94}$ See, e.g., Michael D. Ramsey, International Law as Part of Our Law: A Constitutional Perspective, 29 Pepperdine L Rev 187 (2001).

${ }^{95}$ See, e.g., Alexander Aleinikoff, International Law, Sovereignty, and American Constitutionalism: Reflections on the Customary International Law Debate, 98 Am J Intl L 91 (2003); Ernest A. Young, Sorting Out the Debate Over Customary International Law, 42 Va J Int L 365 (2002).

${ }^{96} 28$ USC $\$ 1350$.

${ }^{97} 630$ F2d 876 (2d Cir 1980).

${ }^{98}$ Id at 887 . The court also incorrectly asserted that the law of nations "has always been part of the federal common law." Id at $\mathbf{8 8 5}$.
} 
people from brutal violence." 99 The author of the opinion, Judge Irving Kaufman, extended this theme in a subsequent magazine article commenting on the decision, writing that "the articulation of evolved norms of international law by the courts" helps "form the ethical foundations for a more enlightened social order." ${ }^{100}$ In other words, the court viewed its federal common law authority as a means of effectuating the needs of the international system and the court's views about the proper place of the United States in that system.

The Supreme Court's 2004 decision in Sosa v Alvarez-Machain was at least an initial step toward rejection of an internationalist approach to the application of customary international law. ${ }^{101}$ In that case, the Court finally considered the propriety of using the Alien Tort Statute as a vehicle for international human rights litigation. While the Court held that a "modest" number of such claims could be pursued under the statute, the Court made clear that this conclusion stemmed from congressional authorization, not some independent judicial authority to effectuate international law. Thus, while the Court concluded that the Alien Tort Statute "was meant to underwrite litigation of a narrow set of common law actions derived from the law of nations," it also made clear that there was "no congressional mandate to seek out and define new and debatable violations of the law of nations." 102 The Court further emphasized that "the general practice has been to look for legislative guidance before exercising innovative authority over substantive law," and that courts should be "wary of impinging on the discretion of the Legislative and Executive Branches in managing foreign affairs."103

The limiting function of the judicial power embraced in SanchezLlamas suggests that the Roberts Court may move even further toward the constitutionalist perspective on this issue. The Court made clear in Sanchez-Llamas that to the extent that international law (in that case, a treaty right) comes into the U.S. legal system, it comes in subject to the usual remedial and procedural doctrines governing the application of domestic law. In Sanchez-Llamas, those

\footnotetext{
${ }^{99}$ Id at 890.

${ }^{100}$ Irving R. Kaufman, A Legal Remedy for Intermational Torture? NY Times Mag 44 (Nov 9, 1980).

101542 US 692 (2004).

${ }^{102}$ Id at $721,728$.

${ }^{103}$ Id at 726,727 .
} 
doctrines included stare decisis, procedural default, and limits on criminal law remedies. In the context of the customary international law debate, the relevant limits are those applicable to post-Erie federal common law, including most notably the requirement that this law be derived from, and be consistent with, extant federal law. ${ }^{104}$ The judicial federalism aspects of Sanchez-Llamas, discussed above, are also part of the limitations on post-Erie federal common law that are potentially relevant to the domestic judicial incorporation of customary international law. ${ }^{105}$

4. Scope of the "Charming Betsy" canon. There is a long-standing canon of construction pursuant to which U.S. courts will attempt to construe statutes, where reasonably possible, to avoid violations of international law. ${ }^{106} \mathrm{~A}$ likely justification for the canon is that it helps the United States avoid unintended violations of international law by forcing the political branches to be clear when they intend to violate it. ${ }^{107}$ Internationalist commentators have attempted to reshape the canon, however, so that it would become a vehicle for expanding U.S. law to be aligned more closely to the contours of international law, and for limiting the discretion of the political branches.

An early example of this effort was an attempt to have courts construe the Foreign Sovereign Immunities Act to disallow immunity for serious human rights violations, on the theory that there was no right to such immunity under international law. The Act specifically lists the grounds under which foreign sovereigns may be denied immunity and does not have a provision for human rights

${ }^{104}$ For an extended argument to this effect, see Curtis A. Bradley, Jack L. Goldsmith, and David H. Moore, Sosa, Customary International Law, and the Continuing Relevance of Erie, 120 Harv L Rev 869 (2007).

${ }^{105}$ Cf. Thomas W. Merrill, The Common Law Powers of Federal Courts, 52 U Chi L Rev 1, 15 (1985) ("[T]he federalism principle identified by Erie still exists but has been silently transformed from a general constraint on the powers of the federal government into an attenuated constraint that applies principally to one branch of that government-the federal judiciary.").

${ }^{106}$ See Restatement (Third), $\$ 114$ ("Where fairly possible, a United States statute is to be construed so as not to conflict with international law or with an international agreement of the United States.") (cited in note 91); Murray v Schooner Charming Betsy, 2 Cranch 64,118 (1804) (" $[\mathrm{A}] \mathrm{n}$ act of Congress ought never to be construed to violate the law of nations if any other possible construction remains.").

${ }^{107}$ See Curtis A. Bradley, The Charming Betsy Canon and Separation of Powvers: Retbinking the Interpretive Role of International Law, 86 Georgetown L J 479 (1998). See also Einer Elhauge, Preference-Eliciting Statutory Default Rules, 102 Colum L Rev 2162, 2238-41 (2002). 
violations. ${ }^{108}$ Nevertheless, some judges and commentators argued that the Act's provision for implied waiver of immunity should be construed as extending to situations in which foreign states effectively "waived" their immunity internationally by engaging in egregious conduct. ${ }^{109}$ To date, all the circuit courts to consider this argument have rejected it, reasoning that their obligation is to apply the statute that Congress enacted, not mold it to the contours of international law. ${ }^{110}$ This is also arguably the subtext of the Supreme Court's 1989 decision in Argentine Republic v Amerada Hess Shipping Corp., in which the Court rejected an Alien Tort Statute-based exception to sovereign immunity. ${ }^{111}$

A more recent effort has concerned the Authorization for the Use of Military Force (AUMF) that Congress enacted in the wake of the September 11 attacks. The AUMF broadly authorizes the Executive to use "all necessary and appropriate force" against those responsible for the attacks. Some commentators have argued, citing to the Charming Betsy canon, that this authorization statute should be read "consistently" with international law, such that it would disallow interrogation and detention practices inconsistent with the Geneva Conventions. ${ }^{112}$ Used this way, the canon would become a vehicle for judicial supervision of Executive Branch compliance with international law, rather than a doctrine designed to promote political branch deliberation. ${ }^{113}$ Courts have not yet shown an inclination to read the AUMF in this fashion. In Hamdi $v$ Rumsfeld, ${ }^{114}$ the Supreme Court construed the AUMF as authorizing the "incidents of war" and conditioned the exercise of that authority only on compliance with constitutional requirements, not international law. In Hamdan $v$ Rumsfeld, ${ }^{115}$ the Court rejected the argument that

${ }^{108}$ See 28 USC $\$ \$ 1602-11$.

${ }^{109}$ See, e.g., Princz v Federal Republic of Germany, 26 F3d 1166, 1183-84 (DC Cir 1994) (Wald, J, dissenting); Adam C. Belsky et al, Comment, Implied Waiver Under the FSLA: A Proposed Exception to Immunity for Violations of Peremptory Norms of International Law, 77 Cal L Rev 365 (1989).

${ }^{110}$ See, e.g., Sampson v Federal Republic of Germany, 250 F3d 1145 (7th Cir 2001).

"I" See 488 US 428 (1989).

${ }^{112}$ See, e.g., Harold Hongju Koh, The Case Against Military Commissions, 96 Am J Intl L 337, 341 n 24 (2002); Ingrid Brunk Wuerth, Authorizations for the Use of Force, International Law, and the Charming Betsy Canon, 46 BC L Rev 93 (2005).

${ }^{113}$ See Curtis A. Bradley and Jack L. Goldsmith, Congressional Authorization and the War on Terrorism, 118 Harv L Rev 2047, 2098-99 (2005) (criticizing this use of the canon).

${ }^{11+} 542$ US 507 (2004).

115126 S Ct 2749 (2006). 
the AUMF expanded President Bush's preexisting statutory authority to create military commissions, and it found that Congress in the Uniform Code of Military Justice had imposed international law restrictions on the use of military commissions, but the Court did not rely on the Charming Betsy canon.

Perhaps the most dramatic effort to extend Charming Betsy is with respect to constitutional interpretation. A number of commentators have argued that, just as with statutes, courts should construe the Constitution to avoid violations of international law. ${ }^{116}$ It has been argued, for example, that the Eighth Amendment's "cruel and unusual punishments" clause should be interpreted to prohibit punishments disallowed under international law. ${ }^{117}$ This would involve a substantial extension of the canon, since a narrower construction of the Constitution in these instances would not actually place the United States in violation of international law. ${ }^{118}$ The Constitution does not mandate particular punishments, for example, regardless of how narrowly the Eighth Amendment is construed. Rather, such punishments are mandated by federal and state law, and if those laws are unambiguous there is no role for the Charming Betsy canon of construction. ${ }^{119}$ Indeed, the United States would not be in violation of international law even if it lacked an Eighth Amendment, and even if it lacked a Constitution. It would violate international law only if it imposed punishments that violated international standards.

More importantly, this extension of the Charming Betsy canon calls upon the courts to use their interpretive power not to avoid an unintended violation of international law, but rather to ensure that the political branches do not violate international law or ac-

${ }^{116}$ See, e.g., Daniel Bodansky, The Use of International Sources in Constitutional Opinion, $32 \mathrm{Ga} J$ Intl \& Comp L 421, 427 (2004); Gordon A. Christenson, Using Human Rights Law to Inform Due Process and Equal Protection Analyses, 52 U Cin L Rev 3, 36 (1983); Joan Fitzpatrick, The Relevance of Customary International Law Norms to the Deatb Penalty in the United States, 25 Ga J Intl \& Comp L 165, 179 (1995-96).

${ }^{117}$ See, e.g., Fitzpatrick, 25 Ga J Intl \& Comp L at 179 (cited in note 116).

${ }^{118}$ See Curtis A. Bradley, The Fuvenile Death Penalty and International Law, 52 Duke L J 485, 555-56 (2002) (explaining this point). See also Roger P. Alford, Four Mistakes in the Debate on "Outsourcing Autbority," 69 Alb L Rev 653, 673-74 (2006) (criticizing efforts to apply the Charming Betsy canon to the Constitution); John O. McGinnis, Contemporary Foreign and International Law in Constitutional Construction, 69 Alb L Rev 801, 803 n 4 (2006) (same).

${ }^{119}$ Cf. Fund for Animals, Inc. $v$ Kemptborne, 472 F3d 872 (DC Cir 2006) (emphasizing that the canon about avoiding international law violations applies only when a statute is ambiguous). 
quiesce in a violation of international law by the states. Instead of reserving the issue of international law compliance to the political branches, this approach attempts to take the issue away from the political process by constitutionalizing it. ${ }^{120}$

These efforts to expand the Charming Betsy canon to give courts a more affirmative role in aligning U.S. law with international law, and overseeing political branch compliance with international law, are at odds with the limited judicial role envisioned in SancbezLlamas. The Court there carefully restricted itself to the bounds of the particular treaty provision in question, and disclaimed independent remedial authority to help effectuate enforcement of the provision, even when such authority would align the United States more closely to the position of an international tribunal. As the Court explained, "our authority to create a judicial remedy applicable in state court must lie, if anywhere, in the treaty itself."121

\section{B. THE JUDICIAL POWER AS PROTECTION}

The protective function of the judicial power envisioned in Sanchez-Llamas also has potential implications for U.S. foreign relations law. Most notably, it suggests that regardless of whether the nondelegation doctrine has vitality in the international arena, there are limits on the extent to which the federal judicial power may be delegated to international institutions. These limits, as I will explain, are likely to be enforced most commonly through a presumption that the decisions and orders of international institutions are "non-self-executing" in the U.S. legal system. I also consider here the potential relevance of these limitations for the Supreme Court's citation of foreign and international materials in its constitutional interpretation decisions.

1. Limits on adjudicative delegations. There is a growing debate over whether the Constitution limits the extent to which the United States can delegate authority to international institutions. ${ }^{122}$ A central issue in this debate is the proper analogy. If

\footnotetext{
${ }^{120}$ As explained in subsection B, the Supreme Court's controversial citation of foreign and international materials in recent constitutional interpretation decisions is distinguishable.

$121126 \mathrm{~S}$ Ct at 2679.

${ }^{122}$ Compare, for example, Julian G. Ku, The Delegation of Federal Power to International Organizations: New Problems with Old Solutions, 85 Minn L Rev 71 (2000), with David Golove, The New Confederalism: Treaty Delegations of Legislative, Executive, and 7udicial
} 
delegations of authority to international institutions are properly analogized to delegations of authority from Congress to U.S. administrative agencies, they may seem unproblematic, given the weakness of the nondelegation doctrine in the administrative agency context. The nondelegation doctrine has been applied to invalidate legislative delegations in only two cases, both decided in 1935, and the doctrine has often been described as having little if any modern vitality. Moreover, Supreme Court precedent suggests that, if anything, there are even fewer restraints on congressional delegations to the Executive in the area of foreign affairs. ${ }^{123}$

On the other hand, it is not clear that this is the proper analogy, since, unlike the Executive, international institutions have no direct electoral connection to U.S. voters. Moreover, international institutions are not subject to the public notice and comment, and congressional oversight, applicable to U.S. administrative agencies. An alternative analogy would be to delegations of governmental authority to private actors, which, although often allowed, are probably subject to greater constitutional restraints than delegations to the Executive. ${ }^{124}$

Most of the focus in this debate has been on legislative and regulatory delegations. Whatever the outcome of that debate, Sanchez-Llamas suggests that, at the very least, nondelegation concerns will have force in the context of international adjudicative delegations. In considering the weight to be given to the ICJ's interpretation of Article 36 of the Vienna Convention, the Court in Sanchez-Llamas noted that Article III of the Constitution vests the judicial power in the federal courts, and that this power extends to the interpretation of treaties. As a result, the Court reasoned, "If treaties are to be given effect as federal law under our legal system, determining their meaning as a matter of federal law 'is emphatically the province and duty of the judicial department,' headed by the 'one supreme Court' established by the Constitu-

Autbority, 55 Stan L Rev 1697 (2003). See also Edward Swaine, The Constitutionality of International Delegations, 104 Colum L Rev 1492 (2004).

${ }^{123}$ See, e.g., United States $v$ Curtiss-Wright Export Corp., 299 US 304, 315 (1936). But cf. $N R D C v E P A, 464$ F3d 1, 9 (DC Cir 2006) (concluding that, if certain regulatory decisions made by the parties to the Montreal Protocol constituted binding law, it "would raise serious constitutional questions in light of the nondelegation doctrine, numerous constitutional procedural requirements for making law, and the separation of powers").

${ }^{124}$ I develop this analogy further in a forthcoming article, Constitutional Process, Treaty Amendments, and Accountability, which will be published in Law \& Contemporary Problems. 
tion." 125 The Court therefore resisted the conclusion that the President and Senate had delegated to the ICJ the authority to bind federal courts to its treaty interpretations.

There are a number of reasons why nondelegation concerns are likely to be given weight in the adjudicative context even if courts do not scrutinize other types of international delegations. First, whereas delegations of legislative or regulatory authority involve voluntary transfers of authority from the branches of government that would normally exercise that authority, with adjudicative delegations the political branches are delegating another branch's (i.e., the judiciary's) authority. Arguments about institutional consent and accountability for the initial delegation are therefore less applicable here. ${ }^{126}$

Second, the case law concerning limits on delegations to nonArticle III tribunals, while hardly determinate, is more substantial than the case law for the nondelegation doctrine. Article III nondelegation concerns led the Supreme Court to invalidate the bankruptcy court system established by Congress in the early $1980 \mathrm{~s},{ }^{127}$ and, in upholding adjudicative delegations in other modern cases, the Court has repeatedly reaffirmed the existence of limits on the extent to which adjudicative authority can be vested in non-Article III tribunals. ${ }^{128}$ Moreover, in other decisions that do not involve delegations per se, the Court has shown a willingness to guard the Article III judicial power from erosion. ${ }^{129}$ There is also longstanding precedent to draw upon, including Hayburn's Case (which

${ }^{125} 126 \mathrm{~S} \mathrm{Ct}$ at 2684.

${ }^{126}$ Cf. Eric A. Posner and Adrian Vermeule, Interring the Nondelegation Doctrine, $69 \mathrm{U}$ Chi L Rev 1721 (2002) (relying on such arguments in questioning the nondelegation doctrine); see also id at 1755 ("Congress couldn't, for example, transfer to executive agents a power that the Constitution vests in some other institution, such as the Supreme Court."). For a similar reason, one could question the ability of the Senate and President to delegate, through a treaty, the full Congress's authority to determine whether the United States should go to war (assuming it has such authority). See Curtis A. Bradley, International Delegations, the Structural Constitution, and Non-Self-Execution, 55 Stan L Rev 1557, 1569-70 (2003).

${ }^{127}$ See Northern Pipeline Construction Co. v Maratbon Pipe Line Co., 458 US 50 (1982).

${ }^{128}$ See, e.g., Peretz v United States, 501 US 923, 936-39 (1991); Commodity Futures Trading Commission v Scbor, 478 US 833, 847-56 (1986); Thomas v Union Carbide Agricultural Products Co., 473 US 568, 582-89 (1985).

${ }^{129}$ See, e.g., Plaut $v$ Spendtbrift Farm, Inc., 514 US 211, 218-19 (1995) (holding that it was unconstitutional for Congress to retroactively reopen final judgments by Article III courts because doing so interfered with the power of the federal judiciary " to render dispositive judgments.") (quoting Frank Easterbrook, Presidential Review, 40 Case W L Rev 905, 926 (1990)). 
has come to stand for the proposition that Congress generally cannot vest the review of decisions of Article III courts in the Executive Branch), ${ }^{130}$ and United States $v$ Klein (which, although its holding is not very clear, may limit the ability of Congress to determine how federal courts adjudicate a case). ${ }^{131}$ Ex parte Milligan, the famous Civil War-era decision disallowing the trial of a U.S. citizen by military commission (and much discussed in connection with the current war on terrorism), was also premised in part on Article III nondelegation concerns. ${ }^{132}$ Scholarly commentary on the issue, while divided with respect to the proper organizing principle, does not evidence the same wholesale retreat as is the case with respect to the administrative nondelegation doctrine. ${ }^{133}$

Finally, as a predictive matter, one can expect that the federal courts will be more solicitous in preventing the loss of their own authority than that of the other branches. ${ }^{134}$ In other modern contexts, the Supreme Court has resisted what it has perceived as political branch challenges to its judicial authority. ${ }^{135}$ The latest indication of this is of course Sanchez-Llamas itself. The Court's approach in Sanchez-Llamas was foreshadowed in the earlier Breard decision, in which the Court emphasized that, notwithstanding a

\footnotetext{
${ }^{130}$ See 2 Dall 409 (1792). See also Miller v French, 530 US 327, 343 (2000) (describing Hayburn's Case).

${ }^{131}$ See 13 Wall 128, 146 (1872) (suggesting that Congress may not "prescribe rules of decision to the Judicial Department of the government in cases pending before it"). But cf. Plaut, 514 US at 218 ("Whatever the precise scope of Klein . . . later decisions have made clear that its prohibition does not take hold when Congress 'amend[s] applicable law."') (citation omitted).

${ }^{132}$ See 4 Wall 2, 121 (1866) ("Every trial involves the exercise of judicial power; and from what source did the military commission that tried him derive their authority? Certainly no part of the judicial power of the country was conferred on them; because the Constitution expressly vests it 'in one supreme court and such inferior courts as the Congress may from time to time ordain and establish,' and it is not pretended that the commission was a court ordained and established by Congress.").

${ }^{133}$ See, e.g., James E. Pfander, Article I Tribunals, Article III Courts, and the fudicial Power of the United States, 118 Harv L Rev 643, 647-48 (2004) (describing academic theories).

${ }^{134}$ As lifetime appointees generally removed from party politics, Supreme Court Justices are more likely to be protective of institutional interests than members of Congress. Cf. Daryl J. Levinson and Richard H. Pildes, Separation of Parties, Not Powers, 119 Harv L Rev 2311 (2006) (arguing that members of Congress are unlikely to be institutionally protective, especially when Congress is controlled by the President's party).

${ }^{135}$ See, e.g., Boerne $v$ Flores, 521 US 507, 536 (1997) ("When the political branches of the Government act against the background of a judicial interpretation of the Constitution already issued, it must be understood that in later cases and controversies the Court will treat its precedents with the respect due them under settled principles, including stare decisis, and contrary expectations must be disappointed.").
} 
provisional order from the ICJ calling for a stay of execution, "this Court must decide questions presented to it on the basis of law."136 The Hamdan decision, decided a day after Sancbez-Llamas, also fits this pattern, since the Court there emphasized the ultimate authority of the federal courts to interpret the relevant law. ${ }^{137}$

2. Presuming non-self-execution. None of this is to suggest that delegations of adjudicative authority to international institutions are inherently problematic, or that the Supreme Court will impose significant constitutional restraints on the ability of the United States to agree to such delegations. The United States has agreed to have international arbitral tribunals resolve treaty disputes since the early days of the nation, so some assignment of adjudicative authority to international actors is certainly allowed. Moreover, the Court's current standard for determining whether delegations to non-Article III tribunals are permissible is highly contextual and indeterminate, ${ }^{138}$ and, especially in the international context, may require judgments for which the courts lack sufficient expertise. In addition, a central factor considered by the Courtwhether the dispute in question concerns "public rights" (e.g., civil disputes between the government and private parties that historically could have been determined exclusively by the government) - may often weigh in favor of the permissibility of international delegations. ${ }^{139}$

\footnotetext{
${ }^{136} 523$ US at 378. See also Sandra Day O'Connor, Federalism of Free Nations, 28 NYU J Intl L \& Pol 35, 36-42 (1995-96) (raising the possibility that the vesting of decisionmaking authority in international tribunals would violate Article III).

${ }^{137}$ See $126 \mathrm{~S} \mathrm{Ct}$ at 2775 ("Together, [federal statutes] at most acknowledge a general Presidential authority to convene military commissions in circumstances where justified under the 'Constitution and laws,' including the law of war. Absent a more specific congressional authorization, the task of this Court is . . to decide whether Hamdan's military commission is so justified.").

${ }^{138}$ In evaluating whether such a delegation is permissible, the Supreme Court considers, among other things, "the extent to which the non-Article III forum exercises the range of jurisdiction and powers normally vested only in Article III courts, the origins and importance of the right to be adjudicated, and the concerns that drove Congress to depart from the requirements of Article III." Schor, 478 US at 851. The Court's ultimate functional inquiry is whether the delegation "impermissibly threatens the institutional integrity of the Judicial Branch." Id.

${ }^{139}$ This may be what saves the NAFTA Chapter 19 arbitral panels, which review whether a U.S. administrative agency has correctly applied U.S. law in making certain import decisions. See Ethan Boyer, Article III, The Foreign Relations Power, and the Binational Panel System of NAFTA, 13 Intl Tax and Bus Lawyer 101 (1996). Cf. Matthew Burton, Note, Assigning the Fudicial Power to International Tribunals: NAFTA Binational Panels and Foreign Affairs Flexibility, 88 Va L Rev 1529 (2002) (defending the constitutionality of the tribunals based on the special need for flexibility in foreign affairs).
} 
Because of the doctrinal uncertainties and difficulties of judicial line-drawing in this context, it is likely that Article III nondelegation concerns will be addressed most commonly through interpretive canons. Indeed, in domestic cases, the Court already uses the constitutional avoidance canon as a means of giving effect to Article III nondelegation concerns. In Gomez $v$ United States, ${ }^{140}$ for example, the Court construed the Federal Magistrates Act as not authorizing felony jury trial selection by magistrates, noting, "It is our settled policy to avoid an interpretation of a federal statute that engenders constitutional issues if a reasonable alternative interpretation poses no constitutional question."141

Importantly, the Court in Sanchez-Llamas did not suggest that the United States' delegation of judicial authority to the ICJ to resolve disputes under the Vienna Convention (through the Optional Protocol) was constitutionally problematic. The Court's Article III concern, rather, related to the domestic effect of the ICJ decision-the determination of the meaning of treaties "as a matter of federal law." ${ }^{142}$ As I have argued elsewhere, courts can generally address this concern by presuming that the decisions of international adjudicative institutions are "non-self-executing" in the U.S. legal system-that is, that they do not by themselves create a rule of decision for U.S. courts. ${ }^{143}$ By requiring political branch implementation, this presumption subjects international decisions to the filter of the U.S. democratic process, while preserving the traditional role of the federal courts to interpret and apply existing domestic law.

The D.C. Circuit has applied this non-self-execution approach in a number of cases involving the orders and decisions of international institutions. In Diggs $v$ Richardson, the court concluded that a Security Council resolution prohibiting certain contacts with apartheid South Africa did not "confer on individual citizens rights that are judicially enforceable in American domestic

\footnotetext{
${ }^{140} 490$ US 858 (1989).

${ }^{141}$ Id at 864 . More controversially, the Court also uses this interpretive approach to address constitutional concerns associated with delegations from Congress to administrative agencies. See John F. Manning, The Nondelegation Doctrine as a Canon of Avoidance, 2000 Supreme Court Review 223; Cass R. Sunstein, Nondelegation Canons, 67 U Chi L Rev 315 (2000).

$142126 \mathrm{~S} \mathrm{Ct}$ at 2684.

${ }^{143}$ See generally Bradley, 55 Stan L Rev at $1587-95$ (cited in note 126).
} 
courts." 144 Similarly, in Committee of United States Citizens Living in Nicaragua $v$ Reagan, ${ }^{145}$ the court reasoned that an ICJ decision prohibiting the United States from assisting rebel forces in Nicaragua was non-self-executing because the relevant treaty provisions evidenced "no intent to vest citizens who reside in a U.N. member nation with authority to enforce an ICJ decision against their own government." ${ }^{146}$ Most recently, in NRDC $v E P A,{ }^{147}$ the court held that decisions of the parties under the Montreal Protocol did not have the status of "judicially enforceable domestic law," reasoning that such status would raise "significant constitutional problems." 148

3. Citation of foreign and international materials. The Court's resistance in Sanchez-Llamas to giving substantial weight to the ICJ's reasoning might be contrasted with recent decisions in which the Court has cited foreign and international materials in resolving issues of constitutional interpretation. ${ }^{149}$ This practice has generated significant controversy, both in the academy and among policymakers. ${ }^{150}$ Internationalist commentators point to the practice as evidence that the Supreme Court is moving to a more global conception of its role. ${ }^{151}$

This practice has been vigorously opposed by some Supreme Court Justices, ${ }^{152}$ and it is possible that the practice will diminish with the new appointments to the Court. ${ }^{153}$ In any event, this practice is distinguishable from efforts to give direct effect to in-

\footnotetext{
${ }^{144}$ See 555 F2d 848, 851 (DC Cir 1976).

${ }^{145} 859$ F2d 929 (DC Cir 1988).

${ }^{1+6}$ Id at 938 .

${ }^{147} 464$ F3d 1 (DC Cir 2006).

${ }^{148}$ Id at 9 . The court also suggested more broadly that the decisions were mere political commitments rather than binding international obligations.

${ }^{149}$ See, e.g., Roper $v$ Simmons, 543 US 551 (2005); Lawrence v Texas, 539 US 558, 572-73 (2003); Atkins v Virginia, 536 US 304, 316 n 21 (2002).

${ }^{150}$ Compare, for example, Harold Hongju Koh, International Law as Part of Our Law, 98 Am J Intl L 43 (2004), with John O. McGinnis, Foreign to Our Constitution, $100 \mathrm{Nw}$ U L Rev (2006).

${ }^{151}$ See, e.g., Melissa Waters, Mediating Norms and Identity: The Role of Transnational Fudicial Dialogue in Creating and Enforcing International Law, 93 Georgetown LJ 487 (2005).

${ }^{152}$ See, e.g., Roper, 543 US at 622-28 (Scalia, J, dissenting, along with Rehnquist and Thomas).

${ }^{153}$ In their confirmation hearings, both Chief Justice Roberts and Justice Alito suggested skepticism about reliance on foreign and international materials in constitutional interpretation. There may still be five Justices, however, that support such reliance.
} 
ternational adjudicatory decisions. The Court has treated foreign and international materials as evidence that may be relevant to the interpretation of vague or uncertain constitutional provisions, not as sources of law that have direct and binding application in the U.S. legal system. Nor has it purported to use these materials in a Charming Betsy sort of way-that is, the Court has not claimed that the Constitution must be interpreted to avoid being inconsistent with these materials. Even in the Court's broadest endorsement of the practice-in the juvenile death penalty decision, Roper $v$ Simmons - the Court made clear that, although the opinion of the world community may provide "respected and significant confirmation" for the Court's conclusions, it is "not controlling." 154 This phrasing is similar to the "respectful consideration" that the Court in Sanchez-Llamas gave to the ICJ's reasoning.

Thus, as currently applied by the Court, the citation of foreign and international materials is not a threat to the Article III judicial power. The foreign and international materials are subject to discretionary selection by the Court, and are treated as nonbinding. This practice is in fact best viewed as potentially enbancing judicial discretion by giving the Court a broader array of materials to draw from in rationalizing its constitutional interpretations. Regardless of whether this practice is a proper method of constitutional interpretation, it is not likely to erode the authority of the federal courts.

\section{IMPLICATIONS FOR ENFORCING THE PRESIDENT'S MEMORANDUM}

Because the petitioners in Sanchez-Llamas were not part of the group of fifty-one Mexican nationals directly covered by the ICJ's judgment in Avena, the Court did not need to consider the legal status or effect of President Bush's February 2005 memorandum, in which he stated that the United States would give effect to the ICJ's judgment in its state courts. The Court simply noted in passing that "the United States has agreed to 'discharge its international obligations' in having state courts give effect to the decision in Avena." 155

During the prior Term, the Court had before it a case that did

${ }^{154} 543 \mathrm{US}$ at 578.

${ }^{155} 126 \mathrm{~S} \mathrm{Ct}$ at 2685. 
involve one of the fifty-one Mexican nationals, Medellin v Dretke. ${ }^{156}$ The Court initially granted a writ of certiorari in that case, but subsequently dismissed the writ as improvidently granted. A principal reason for the dismissal was the possibility that Medellin might obtain the relief he was seeking in a Texas state court, as a result of the President's memorandum. ${ }^{157}$

After Sanchez-Llamas, however, the Texas Court of Criminal Appeals denied relief to Medellin, holding that the President's memorandum did not override Texas's law of procedural default. ${ }^{158}$ In reaching this conclusion, the Texas court noted that the $\mathrm{Su}$ preme Court in Sanchez-Llamas had concluded that Article 36 of the Vienna Convention does not override state rules of procedural default, and that the ICJ's reasoning in Avena is not binding on U.S. courts. As a result, the Texas court concluded that neither Article 36 nor the Avena judgment created a legal basis for overriding Texas's law. With respect to the President's memorandum, the court, invoking the Youngstown steel seizure decision, reasoned that the President lacked the power to create preemptive federal law, and that the memorandum improperly "intrud[ed] into the independent powers of the judiciary." $" 159$

The implications of Sanchez-Llamas for the enforceability of the President's memorandum are less clear than this analysis suggests. As an initial matter, Sancbez-Llamas did not consider the effect of the ICJ's judgment, as opposed to its reasoning. It would not be illogical for the Court to both disagree with the ICJ's reasoning, as it did in Sanchez-Llamas, and nevertheless enforce the ICJ's judgment, just as U.S. courts often enforce foreign court judgments and commercial arbitral awards without endorsing their underlying reasoning. To be sure, ICJ judgments may be distinguishable in this regard given the interstate nature of ICJ dispute resolution and the subject matter of the disputes addressed by the ICJ, ${ }^{160}$ but the Court in Sanchez-Llamas did not address that issue. More fundamentally, Sanchez-Llamas is ultimately a decision

\footnotetext{
${ }^{156}$ See 544 US 660 (2005).

${ }^{157}$ Id at 666-67; see also id at 669 (Ginsburg, J, concurring).

${ }^{158}$ See Ex parte Medellin, 2006 Tex Crim App LEXIS 2236 (Tex Ct Crim App, Nov 15, 2006).

${ }^{159}$ Id at ${ }^{*} 45$.

${ }^{160}$ See Curtis A. Bradley, Enforcing the Avena Decision in U.S. Courts, 30 Harv J L \& Pub Pol 119 (2006); Mark L. Movsesian, Understanding Sanchez-Llamas (draft on file with author).
} 
about judicial power, not Executive power. The Court made clear in Sanchez-Llamas that the judiciary lacks the authority to create remedies or legal rules that go beyond the terms of a treaty, even for the sake of facilitating enforcement of the treaty. While the Court also suggested that the judiciary should be protected from outside control, its focus was on control by non-U.S. actors, not the Executive. Indeed, the Court noted that U.S. courts should give deference to Executive Branch treaty constructions. ${ }^{161}$

The decision in Sancbez-Llamas therefore does not preclude the possibility that the Executive has some remedial lawmaking authority in this context not possessed by the judiciary, perhaps stemming from the President's obligation to "take Care that the Laws be faithfully executed." "62 Even though Article 36 of the Vienna Convention may not override state procedural default rules (as both the Executive and the Supreme Court have now concluded), the United States still has a treaty obligation to comply with the ICJ's judgment, pursuant to Article 94 of the United Nations Charter. ${ }^{163}$ While Article 94 is almost certainly non-self-executing-that is, it does not of its own force give domestic effect to ICJ judgments ${ }^{164}$ - the President's Take Care authority may include some ability to give legal effect to a non-self-executing treaty obligation. Or, to put it slightly differently, Article 94 could be read as implicitly delegating to the Executive Branch some authority to implement ICJ decisions, in the same way that foreign affairs statutes are often construed as implicitly delegating authority to the Executive. ${ }^{165}$

Certainly there must be limits on the authority of the President to create preemptive federal law, even in the area of foreign relations. Dicta in American Insurance Association v Garamendi sug-

${ }^{161}$ See $126 \mathrm{~S} C t$ at 2685.

${ }^{162}$ US Const, Art II, $\$ 3$.

${ }^{163}$ See UN Charter, Art 94(1) ("Each member of the United Nations undertakes to comply with the decision of the International Court of Justice in any case to which it is a party.").

${ }^{164}$ See Committee of United States Citizens Living in Nicaragua $v$ Reagan, 859 F2d 929, 937-38 (DC Cir 1988); A. Mark Weisburd, International fudicial Decisions, Domestic Courts, and the Foreign Affairs Power, 2004-05 Cato Sup Ct Rev 287, 299-304. The only enforcement mechanism mentioned in Article 94 is through the UN Security Council. See UN Charter, Art 94(2).

${ }^{165}$ Cf. Curtis A. Bradley, Chevron Deference and Foreign Affairs, 86 Va L Rev 649, 670-71 (2000); Carlos Manuel Vazquez, Breard and the Federal Power to Require Compliance with ICF Orders of Provisional Measures, 92 Am J Intl L 683, 689 (1998). 
gesting that state law can be preempted by the "foreign policy of the Executive Branch" ${ }^{166}$ has been appropriately criticized. ${ }^{167}$ The Supreme Court would not need to go as far as that dicta, however, to enforce the President's memorandum, since the underlying treaty commitment to comply with the ICJ's judgment makes compliance more than simply the foreign policy of the Executive Branch. Indeed, the Texas court acknowledged that the President might be able to accomplish this by entering into an executive agreement with Mexico. ${ }^{168}$ If this is the case (and there may be federalism and other grounds for disputing it), it is not clear why the lack of this formality is dispositive. ${ }^{169}$ While requiring an executive agreement would impose a process restraint on the Executive's ability to preempt state law, such a restraint is not (unlike the Article II treaty process, which involves the Senate) one that has any particular relationship to the protection of state interests.

\section{Benefits of the Judicial Power's Two Functions in International Cases}

The constitutionalist approach, as reflected in Sanchez-Llamas, envisions federal judges as agents of the domestic legal system, not the international order. This part outlines several benefits associated with this approach in light of the current nature of the international adjudicative system. In particular, it argues that the constitutionalist approach has the virtues of enhancing democratic input, compensating for the lack of horizontal checks and balances at the international level, allowing international law and decisions to be tailored to local conditions, and facilitating local acceptance of international decision making. It also argues that countervailing arguments about the need for the uniformity and the desirability of enhancing international law compliance are weak in this context.

${ }^{160} 539$ US at 413.

${ }^{167}$ See Brannon P. Denning and Michael D. Ramsey, American Insurance Association v. Garamendi and Executive Preemption in Foreign Affairs, 46 Wm \& Mary L Rev 825 (2004); Michael P. Van Alstine, Executive Aggrandizement in Foreign Affairs Lawmaking, 54 UCLA L Rev 309 (2006).

${ }^{168}$ See 2006 Tex Crim App LEXIS at *66-*67.

${ }^{169}$ But see Weisburd, 2004-05 Cato Sup Ct Rev at 313 (cited in note 164) ("Since the president's power to supersede state law in foreign affairs matters derives from his authority to bargain with foreign governments, the absence of a bargain eliminates any basis for presidential authority."). 


\section{A. THE INTERNATIONAL ADJUDICATIVE "SYSTEM"}

Since World War II and the establishment of the United Nations, there has been a vast growth in the number and types of international institutions. As part of this growth, scores of adjudicative institutions have arisen, sometimes as stand-alone bodies, but often as constituent parts of broader organizations. ${ }^{170}$ There are general tribunals like the ICJ; specialized tribunals in areas such as trade, human rights, and the law of the sea; ad hoc arbitral bodies such as the Iran-U.S. Claims Tribunal; regional tribunals such as in Europe and in the Inter-American system; and criminal tribunals, including the relatively new International Criminal Court (ICC). ${ }^{171}$ Increasingly, in terms of the subject matters that they address and the ways in which they are structured, international adjudicatory institutions are resembling traditional domestic courts rather than simply interstate arbitral mechanisms. Although not a party to all of these institutions (such as the ICC), the United States has connections to many of them.

This description actually understates the extent of, and variations within, the international adjudicative "system." In part because separation of powers is less distinct in the international system than in some domestic systems, many international institutions that are not courts or tribunals nevertheless perform judicial or quasi-judicial functions. The Security Council, for example, routinely decides whether nations have acted in ways that threaten international peace and security. ${ }^{172}$ Monitoring and inspection committees for human rights and arms control regimes regularly issue reports or decisions concerning compliance. ${ }^{173}$ The

${ }^{170}$ See generally Julian G. Ku, International Delegations and the New World Court Order, 81 Wash L Rev 1, 25-31 (2006); Martinez, 56 Stan L Rev at 436-41 (cited in note 2); Cesare P. R. Romano, The Proliferation of International fudicial Bodies: The Pieces of the Puzzle, 31 Intl L and Pol 709 (1999).

${ }^{171}$ For a chart showing 125 international judicial and quasi-judicial bodies and mechanisms, see The Project on International Courts and Tribunals-Synoptic Chart, version 3.0 (Nov 2004), at http://www.pict-pcti.org/publications/synoptic_chart/Synop_C4.pdf.

${ }^{172}$ See, e.g., UN Security Council, Res 1718 (Oct 14, 2006) (concluding that nuclear test by North Korea created a threat to international peace and security and therefore imposing a variety of sanctions).

${ }^{173}$ See, e.g., Concluding Observations of the Human Rights Committee, United States of America, UN Doc A/50/40, para 279 (expressing the view that U.S. reservations to the International Covenant on Civil and Political Rights, including a reservation concerning the use of the death penalty for individuals who committed crimes while under the age of eighteen, were invalid because they were incompatible with the object and purpose of the Covenant); Human Rights Committee, General Comment 24(52), General Comment 
same is true of various international law "commissions," such as the Inter-American Commission on Human Rights, which, although not constituted as a court, has issued a variety of adjudicatory rulings, including some relating to U.S. practices such as the death penalty. ${ }^{174}$ "Conferences of parties" established under treaty regimes also frequently issue quasi-judicial "decisions" about how the treaty should be interpreted or applied. ${ }^{175}$

There are wide variations in the jurisdiction of these various institutions. Some, like the ICJ, can hear disputes only between nation-states. Others, like the Inter-American Court on Human Rights, are open to disputes between states and private parties. Moreover, different states often have differing jurisdictional relationships with the same institution. For example, some states may accept a tribunal's general or compulsory jurisdiction, whereas others may not. For the ICJ, sixty-six states currently accept its compulsory jurisdiction, which is only about one-third of all the members of the United Nations, and many of those sixty-six states have qualified their acceptance of this jurisdiction with reservations. ${ }^{176}$ Similarly, some parties to a treaty may consent to adjudication with respect to disputes that arise under the treaty, while other parties to the treaty may not. For the Vienna Convention on Consular Relations, for example, there are 171 parties to the treaty, but only forty-five of them currently accept ICJ jurisdiction to resolve disputes under the treaty. ${ }^{177}$ In addition, some states

on Issues Relating to Reservations Made Upon Ratification or Accession to the Covenant or the Optional Protocols Thereto, or in Relation to Declarations Under Article 41 of the Covenant, UN Doc CCPR C/21/Rev 1/Add 6 (1994) (expressing views about the circumstances under which reservations to the Covenant are disallowed, and stating that "[i]t necessarily falls to the Committee to determine whether a specific reservation is compatible with the object and purpose of the Covenant").

${ }^{174}$ See, e.g., Inter-American Commission on Human Rights, Report No 62/02, Case 12.285, Michael Domingues, United States (Oct 22, 2002) (concluding that customary international law prohibits the execution of individuals who commit their crimes prior to the age of eighteen).

${ }^{175}$ For example, decisions by the conference of parties under the Montreal Protocol were at issue in the NRDC case described in note 123

${ }^{176}$ See Declarations Recognizing as Compulsory the Jurisdiction of the Court, at http: //www.icj-cij.org/icjwww/ibasicdocuments/ibasictext/ibasicdeclarations.htm. The United States was originally a party to the ICJ's compulsory jurisdiction, but withdrew from that jurisdiction after the ICJ assumed jurisdiction over a case in the 1980 s concerning U.S. military activities in Nicaragua. Only one of the five permanent members of the UN Security Council-Great Britain-is currently a party to the ICJ's compulsory jurisdiction, and its consent to that jurisdiction is subject to the proviso that it can "at any time . . and with effect as from the moment of such notification, either add to, amend or withdraw" any of its reservations to the jurisdiction.

${ }^{17}$ See United Nations Treaty Collection, at http://untreaty.un.org. 
may allow their citizens to file individual complaints with an institution, whereas others may not. This is optional, for example, with the Human Rights Committee that administers the International Covenant on Civil and Political Rights. ${ }^{178}$

Sometimes, even when the relevant parties to a controversy have not agreed to an institution's jurisdiction, the institution will nevertheless address the controversy through the issuance of an advisory opinion. The ICJ has done this on a number of occasions, perhaps most controversially when it opined in 2004 about the legality of Israel's construction of a security barrier in occupied Palestine. ${ }^{179}$ Although the United States is not a party to the InterAmerican Court on Human Rights, that Court has issued a number of advisory opinions relating to practices in the United States, including U.S. compliance with the Vienna Convention. ${ }^{180}$ These advisory opinions are technically not "binding" under international law, although the line between binding and nonbinding international decisions is often unclear in light of the limited enforcement options associated with even binding decisions, as well as the possibility that nonbinding decisions will either be given substantial deference or treated as evidence of binding customary international law.

The jurisdiction of these various institutions frequently overlaps, such that different institutions may address the same questions and potentially reach different conclusions, and there is no established hierarchy among these institutions. ${ }^{181}$ For example, as noted above, both the Inter-American Court on Human Rights and the ICJ have addressed issues of compliance with the Vienna

${ }^{178}$ See Optional Protocol to the International Covenant on Civil and Political Rights, UN Doc A/6316 (1966), 999 UNTS 302, entered into force March 23, 1976.

${ }^{179}$ See Advisory Opinion, Legal Consequences of the Construction of a Wall in the Occupied Palestinian Territory (July 9, 2004), at http://www.icj-cij.org/icjwww/idocket/ imwp/imwpframe.htm. For criticism of the ICJ's exercise of advisory jurisdiction in this case, see Michla Pomerance, The ICJ's Advisory Furisdiction and the Crumbling Wall Between the Political and the Fudicial, 99 Am J Intl L 26 (2005).

${ }^{180}$ See, e.g., Inter-American Court of Human Rights, "The Right to Information on Consular Assistance in the Framework of the Guaranties of the Due Process of Law," Adv Op OC-16/99, Inter-Am Ct HR (Ser A) No 16 (Oct 1, 1999).

${ }^{181}$ See generally Yuval Shany, The Competing furisdictions of International Courts and Tribunals (2003); see also Martinez, 56 Stan L Rev at 431 ("In many situations . . . it is as yet unclear what should happen when more than one court potentially has jurisdiction over the same case; unclear how one court should treat the decisions of another court; and unclear what should happen when courts reach inconsistent decisions.") (cited in note 2). 
Convention, and they have expressed differing views about what the treaty requires. ${ }^{182}$ Similarly, the International Criminal Tribunal for Former Yugoslavia has expressed views contrary to the ICJ concerning state responsibility for the actions of non-actors. ${ }^{183}$

The jurisdiction of international adjudicatory institutions also increasingly overlaps with the jurisdiction of domestic courts. ${ }^{184}$ As its Vienna Convention decisions demonstrate, the ICJ is now addressing issues of domestic criminal law and procedure. International criminal tribunals address crimes that may also be addressed in domestic criminal law. A particularly direct intersection between international adjudication and domestic courts was evident in two NAFTA arbitral cases, Loewen and Mondev, in which NAFTA panels considered whether state court decision making in the United States had violated U.S. treaty obligations. ${ }^{185}$

The appointment process for the members of these institutions varies widely, with none of them appointed with the tenure and salary protections applicable to federal judges. Nor are these appointments typically subject to nearly as much transparency or public deliberation as with domestic judicial appointments. ${ }^{186} \mathrm{Con}$ sider, for example, the ICJ. It consists of fifteen judges, from fifteen different nations. These judges are, according to the ICJ Statute,

\footnotetext{
${ }^{182}$ Whereas the Inter-American Court expressed the view that consular notice must be provided "at the time the accused is deprived of his freedom, or at least before he makes his first statement before the authorities," see Inter-American Court, The Right to Information on Consular Assistance, at para 106 (cited in note 180), the ICJ in Avena expressed the view that the notice should be given "as soon as it is realized that the person is a foreign national, or once there are grounds to think that the person is probably a foreign national" and that the notice need not necessarily be given at the time of the arrest or before questioning, see Case Concerning Avena, at paras 87-88 (cited in note 20).

${ }^{183}$ Compare Case Concerning the Military and Paramilitary Activities in and Against Nicaragua (Nicaragua $v$ United States of America), 1986 ICJ 14, para 115 (1986) (Judgment of 27 June 1986) (adopting narrow "effective control" standard for attribution of private conduct to states), with The Prosecutor $v$ Dusko Tadic, IT-94-1-A, ICTY Appeals Chamber, para 145 (1999) (Judgment of 15 July 1999) (Merits) (adopting broader "overall control" standard).

${ }^{184}$ See Ernest A. Young, Institutional Settlement in a Globalizing Fudicial System, 54 Duke L J 1143 (2005).

${ }^{185}$ See Tbe Loewen Group, Inc. $v$ United States of America, Case No ARB(AF)/98/3 (Award) (June 26, 2003), at http://www.state.gov/documents/organization/22094.pdf; Mondev Int'l Ltd $v$ United States of America, Case No ARB(AF)/99/2 (Award) (Oct 11, 2002), at http:/ /www.state.gov/documents/organization/14442.pdf.

${ }^{186}$ See Ruth Mackenzie and Philippe Sands, International Courts and Tribunals and the Independence of the International fudge, 44 Harv Intl L J 271, 277-78 (2003) ("In practice, the nomination and election of judges to international courts and tribunals are politicized processes, subject to little transparency, and to widely varying nomination mechanisms at the national level.").
} 
supposed to be representative of the "main forms of civilization" and "the principal legal systems of the world." 187 The ICJ's membership has in fact been quite varied, although the five veto members of the Security Council have almost always had a judge on the court. (The current judges on the court are from the United States, the United Kingdom, Jordan, Madagascar, China, Sierra Leone, Venezuela, Japan, Germany, Slovakia, France, New Zealand, Mexico, Morocco, and Russia.) The judges are nominated by "national groups" in the Permanent Court of Arbitration (which are appointed by each nation), and then elected by the UN General Assembly and UN Security Council. These judges serve for nineyear terms and can be reelected. When a judge is elected or reelected to the ICJ, even when it is a U.S. judge, there is almost no public attention or debate in the United States. ${ }^{188}$

In many instances, the judges on international adjudicative bodies are likely to be "biased" in the sense that they will vote according to the preferences of their nation. One study of the ICJ, for example, found that ICJ judges vote for their home state about 90 percent of the time, and when their home state is not a party, they tend to vote for states that are similar to their home state in terms of wealth, culture, and political regime. ${ }^{189}$ This is unsurprising, given that these judges are as a practical matter dependent on their nations for reappointment, and also potentially for other government positions. ${ }^{190}$ As further noted by Eric Posner and Miguel Figueiredo, “These considerations are likely to weigh even more heavily in the calculations of judges from authoritarian states, as these judges do not necessarily have the option to take refuge in the private sector if they displease their government."191 Even without such incentives, however, it is not surprising that judges

${ }^{187}$ ICJ Statute, Art 9.

${ }^{188}$ Based on a LexisNexis search of major newspapers, I could find no mention in U.S. newspapers of the reelection to the ICJ in 2005 of the current American judge, Thomas Buergenthal. Contrast that with the news coverage of the recent appointments of John Roberts and Samuel Alito to the U.S. Supreme Court.

${ }^{189}$ See Eric A. Posner and Miguel de Figueiredo, Is the International Court of fustice Biased? 34 J Legal Stud 539 (2005).

${ }^{190}$ For debate over whether judicial independence is desirable in international tribunals, compare Eric A. Posner and John C. Yoo, Fudicial Independence in International Tribunals, 93 Cal L Rev 1 (2005) (arguing that it is not), with Laurence R. Helfer and Anne-Marie Slaughter, Why States Create International Tribunals: $A$ Response to Professors Posner and Yoo, 93 Cal L Rev 899 (2005) (arguing that it is).

${ }^{191}$ Posner and Figueiredo, $34 \mathrm{~J}$ Legal Stud at 608 (cited in note 189). 
would reflect the particular perspectives of their nations, which might be very different from the perspective of the party countries before them.

In sum, the international adjudicative system is highly varied and fragmented. It has scores of institutions of varying levels of specialization and types of jurisdiction, with often varying relationships to different states. It produces overlapping and sometimes conflicting decisions, some of which are formally binding and some of which are not, and some of which will reflect national biases.

Contrast this with the U.S. Supreme Court and its relationship to U.S. states. There is one centralized Supreme Court, and it has a hierarchical relationship to both the lower federal courts and, for issues of federal law, to the state courts. It applies law that is expressly stated in the Constitution to be part of the supreme law of the land and binding on state judges. Its judges are appointed from the U.S. bar in a process that involves substantial public attention and requires nomination by a nationally elected president and approval by a substantial number of senators, two of whom represent each state. The judges then enjoy lifetime tenure and salary protection. The judges may well be "political" in the sense that their votes are affected by their political preferences, but they are largely removed from direct political influences. In practice, the constitutional decisions of the Court nevertheless hew pretty closely to democratic preferences of the polity. As for its nonconstitutional decisions, they are subject to override by a simple majority of the legislative branch. The Court decides only cases and controversies and will not issue advisory opinions. It now has well over 200 years of history and jurisprudence from which to draw. Perhaps most importantly, it is understood to be the national court for a single country of which the states are constituent parts. Even with all of this, its decisions and authority have sometimes been vigorously questioned, both by the states and by the federal political branches.

The only international adjudicatory institutions that bear some resemblance to the U.S. Supreme Court are two supranational courts in Europe-the European Court of Justice, and the European Court of Human Rights. These institutions are centralized tribunals, embedded in a connected geographic community that 
shares a common drive for integration. ${ }^{192}$ They have broad compulsory jurisdiction that is similar for all the member states, and they have now developed an extensive jurisprudence. Not coincidentally, national court relations with those institutions come closest to the internationalist approach, with national courts generally treating the decisions of those institutions as authoritative. ${ }^{193}$ The United States is of course not a party to these institutions, and they are not representative of the rest of the international adjudicative system.

\section{B. BENEFITS OF THE CONSTITUTIONALIST APPROACH}

In light of the current state of the international adjudicative system, there are a number of benefits to the constitutionalist approach followed in Sanchez-Llamas: enhancing democratic input, helping to compensate for the lack of horizontal checks and balances at the international level, ensuring that international decision making is tailored to local conditions, and facilitating domestic acceptance of such decision making.

First, by limiting judicial remedial creativity and denying international decisions direct domestic effect, the constitutionalist approach enhances democratic input in the domestic application and enforcement of international law. Under this approach, decisions about whether and how to comply with international law are made in the first instance by the democratically accountable political branches, rather than the courts. Such a democratic "filter" is particularly important for international law because the processes of international lawmaking-both treaty-based and customary-are less transparent and involve less accountability than domestic democratic lawmaking. ${ }^{194}$

${ }^{192}$ The European Court of Justice is the adjudicatory body of the European Union, which now has twenty-seven member states. The European Court of Human Rights is part of the Council of Europe, which has forty-six member states. All members of the European Union are also members of the Council of Europe.

${ }^{193}$ Even for those courts, there are mediating doctrines that can limit the intrusiveness of the courts on national decision making, such as the "margin of appreciation" and "subsidiarity." See, e.g., Howard Charles Yourow, The Margin of Appreciation Doctrine in the Dynamics of European Human Rights Jurisprudence (1996); George A. Bermann, Taking Subsidiarity Seriously: Federalism in the European Union and the United States, 94 Colum L Rev 331 (1994).

${ }^{194}$ See generally John O. McGinnis and Ilya Somin, Should International Law Be Part of Our Law? 59 Stan L Rev (forthcoming 2007); Eric Stein, International Integration and Democracy: No Love at First Sight, 95 Am J Intl L 489 (2001); Paul B. Stephan, Accountability 
Customary international law implicates particular democratic legitimacy concerns. ${ }^{195}$ Unlike a statute or treaty, customary international law does not involve any agreed-upon text voted upon by U.S. representatives. Moreover, the most populist branch of the government, the Congress, has at most a very indirect role in the formation of customary international law. Rather, U.S. involvement in customary international law formation comes primarily from the Executive Branch. Nor, even with this involvement, is there any guarantee that the U.S. position will prevail or that customary international law will reflect U.S. legal traditions and culture. The United States simply has one important voice in a community of over 190 diverse nations, many of whom may themselves be undemocratic. Finally, unlike with many treaties, the United States has no unilateral authority to withdraw from customary international law rules once those rules are established.

International adjudicatory institutions, despite offering potential benefits of expertise and enhancement of coordination, add yet another layer of democratic deficit. As noted above, the judges in these institutions are often appointed with little public attention or legislative oversight, and many of them may come from nondemocratic regimes. And, unlike domestic courts, these institutions are not embedded in, or closely monitored by, a domestic society. If U.S. judges were to act as agents of the international order and bypass the political branches with respect to the implementation of international law and decisions, they would only compound the democratic deficit.

A good model for enhancing democratic input is the way in which the United States processes dispute settlement decisions by the World Trade Organization (WTO). The international trade regime, despite its many benefits, is controversial because of its perceived tensions with other values, such as labor and environmental protection, and this controversy is exacerbated by concerns over perceptions about its lack of democratic legitimacy. Congress took account of these concerns in its implementing legislation for the WTO agreements, making clear that WTO dispute settlement decisions must be accepted and implemented by the political

and International Lawmaking: Rules, Rents, and Legitimacy, $17 \mathrm{Nw} \mathrm{J}$ Intl L \& Bus 681 (1996-97).

${ }^{195}$ See Curtis A. Bradley, The Costs of International Human Rigbts Litigation, 2 Chi J Intl L 457, 465 (2001); McGinnis and Somin, 59 Stan L Rev (cited in note 194). 
branches before they are applied by U.S. courts. ${ }^{196}$ This requirement has ensured that there is democratic deliberation before WTO decisions result in changes to U.S. law, but at the same time it has not prevented the United States from complying with even the most controversial WTO decisions.

A second benefit of the constitutionalist perspective is that it helps compensate for the lack of horizontal checks and balances at the international level. Because there is no general legislative or executive body on the international plane, international adjudicative institutions (and other international institutions) typically operate without any significant horizontal supervision or feedback (again, the European institutions are a notable exception). While in theory the parties to the treaty establishing the institution could amend the treaty if the institution makes poor decisions, or exceeds its mandate, such amendments may require a supermajority vote or even unanimity among a highly diverse group of states, so this option is likely to provide only a very limited check.

The constitutionalist approach reflected in Sancbez-Llamas helps compensate for this problem by allowing for a subvertical check on international decision making. Under this approach, international decisions are still binding on the international plane, and nations will have reputational and other incentives to comply with the decisions. International institutions will not, however, be able to enlist domestic courts directly as their enforcement organs. The implementation of these decisions, rather, will turn in part on their persuasiveness on the relevant legal issues.

The usefulness of this subvertical check is illustrated by the ICJ's decision in Avena. The U.S. political branches have repeatedly resisted efforts over the years to have the U.S. death penalty regulated by international law. ${ }^{197}$ Nevertheless, through the Vienna Convention cases, the ICJ moved into the sensitive realm of the death penalty, an issue made even more sensitive in the United States by considerations of federalism. Instead of simply determining whether there were breaches of the Convention (something that was not even contested), the ICJ ultimately opined about the ability of foreign nationals to raise claims under the Vienna Convention in U.S. domestic courts, and the relationship of the

${ }^{196}$ See Bradley, 55 Stan L Rev at 1594-95 (cited in note 126).

${ }^{197}$ See Bradley, 52 Duke L J at 516-35 (cited in note 118). 
Vienna Convention to U.S. domestic procedures. It is unlikely that the United States could have expected these sorts of decisions when it ratified the Vienna Convention's optional protocol in 1969 , but, as noted, there is no meaningful horizontal check on the ICJ's compliance with its jurisdictional mandates. ${ }^{198}$

A subvertical check was also useful in Avena simply because of the unclear and possibly confused nature of some of the ICJ's reasoning. With respect to the issue of procedural default, there are places in both LaGrand and Avena in which the ICJ suggests that the application of procedural default rules is problematic only where the failure of authorities to provide the consular notice is itself responsible for the failure of a defendant's lawyer to raise the violation until after conviction. ${ }^{199}$ It is not clear how this would occur, however, since lawyers in the U.S. system are on constructive notice of their clients' legal rights, including presumably their Vienna Convention rights. By analogy, if a defendant fails to receive a Miranda warning, he is not allowed to raise the Miranda violation for the first time in postconviction proceedings on the theory that he and his lawyer were unaware of Miranda rights because they were not informed of them by the police. It is possible that the ICJ thought that criminal defendants should not bear the consequences of their lawyers' ignorance or mistakes, but, as the majority noted in Sanchez-Llamas, that view would be substantially inconsistent with well-settled features of the U.S. legal system. ${ }^{200}$

In any event, the ICJ never follows up on the idea that a Vienna Convention violation might itself be responsible for a lawyer's failure to raise the violation until after conviction. Rather, it simply concludes without further analysis that the application of procedural default rules in the cases before it violates the treaty, even though in none of those cases was there a showing that the lawyers' failure to raise the claim was caused by the lack of consular notification itself. ${ }^{201}$ If the ICJ believed that the application of procedural default rules to bar Vienna Convention claims inberently violates the treaty, as its holding (although not its reasoning) sug-

\footnotetext{
${ }^{198}$ For other examples of jurisdictional expansion by international institutions over time, see Bradley, 55 Stan L Rev at 1577 (cited in note 126).

${ }^{199}$ See LaGrand, at paras 90-91 (cited in note 16); Case Concerning Avena, at para 112 (cited in note 20).

${ }^{200} \mathrm{See} 126 \mathrm{~S} \mathrm{Ct}$ at $2686 \mathrm{n} 6$.

${ }^{201}$ See Case Concerning Avena, at paras 113, 134 (cited in note 20).
} 
gests, this would mean that even if a defendant's lawyer purposely avoided raising a Vienna Convention claim at trial, the defendant could raise the claim years later, something not allowed even for constitutional claims, even during the days of the Supreme Court's most expansive approach to habeas corpus. ${ }^{202}$

In his dissent in Sanchez-Llamas, Justice Breyer creatively attempted to clarify the ICJ's holding on this issue, suggesting both that a hearing at which the procedural default issue was considered would constitute "review and reconsideration" that would satisfy the ICJ's required remedy, and that procedural default rules could be applied to bar Vienna Convention claims if states allowed defendants to bring an ineffective assistance of counsel claim based on their counsel's failure to raise the Vienna Convention issue in a timely manner. ${ }^{203}$ There is no hint of these glosses in Avena, however, and they would completely negate the ICJ's procedural default holding. If the procedural default hearing would itself satisfy the ICJ's requirements, then it makes no sense for the ICJ to have ruled that U.S. application of procedural default rules violated the treaty. As for the possibility of raising an ineffective assistance of counsel claim, the ICJ was made aware of that possibility in LaGrand, but it did not appear to affect the ICJ's analysis of procedural default. ${ }^{204}$ Moreover, if defendants can in fact bring ineffective assistance of counsel claims based on Vienna Convention violations (as might be the case, subject to the usual stringent requirements of the ineffective assistance of counsel doctrine), then, once again under Justice Breyer's logic, the ICJ's finding of a conflict between the Vienna Convention and procedural default rules was erroneous.

It is possible, of course, that the ICJ, which has only one U.S. judge, was simply confused about how procedural default rules worked in the United States, which has both an adversarial system and a federal system of government. This would be entirely understandable given the complex body of domestic law implicated

\footnotetext{
${ }^{202}$ See Fay $v$ Noia, 372 US 391 (1963) (allowing denial of habeas corpus relief where there has been "deliberate bypass").

${ }^{203}$ See $126 \mathrm{~S} \mathrm{Ct}$ at 2699-2700 (Breyer, J, dissenting).

${ }^{204}$ See LaGrand, at para 71 (noting Germany's argument that "due to the doctrine of procedural default and the high postconviction threshold for proving ineffective counsel under United States law, Germany's intervention at a stage later than the trial phase could not 'remedy the extreme prejudice created by the counsel appointed to represent the LaGrands") (cited in note 16).
} 
by that issue. If so, however, this simply confirms the desirability of the domestic filter entailed by the constitutionalist approach.

A third advantage of the constitutionalist approach to international adjudicatory decisions is that it helps ensure that, when international decisions are implemented domestically, they are tailored to take into account local laws and conditions. Domestic legal systems vary substantially, and international adjudicative institutions will not have significant expertise with respect to any one particular system. As noted, this problem is evident in the ICJ's analysis of U.S. procedural default law in Avena. This is also an issue for international regulatory decisions, such as those issued by the WTO, which often intersect with complex bodies of federal statutory and administrative law, and sometimes state law as well. Even the ICJ seemed to recognize the value of this function in its pre-Avena Vienna Convention decisions, noting in LaGrand, for example, that the "choice of means [for implementing the Article 36 obligations] must be left to the United States."

Finally, this local filtering and tailoring will likely make the decisions more acceptable to those who disagree with them. Domestic actors will have a better sense of how international laws and decisions fit within the broader framework of the domestic legal system, and about what is acceptable in their polity. In a federal system like the United States, this includes considerations of what is acceptable at the state and local levels. ${ }^{205}$ These considerations are particularly significant for international decisions, because, unlike a domęstic court, international adjudicators are not typically able to draw upon a shared experience or culture to enhance acceptance of their decisions. ${ }^{206}$ The U.S. Supreme Court, by contrast, does this regularly. To take just one example, consider Missouri v Holland, in which the Supreme Court (through Justice Holmes, a veteran of the Civil War) reminds readers that the development of the Constitution initiated by the Founders "has taken a century and has cost their successors much sweat and blood to prove that they created a nation," and then observes that " $[t]$ he

${ }^{205}$ See, e.g., Karen Alter, Resolving or Exacerbating Disputes? The WTO's New Dispute Resolution System, 79 Intl Affairs 783, 793 (2003) ("Being products of their national political environment, and working within the same cultural and political context in which they adjudicate, national judges are far more likely to be in harmony with political sentiment.").

${ }^{206}$ See Movsesian, Understanding Sanchez-Llamas (cited in note 160) (making this point); see also Mark L. Movsesian, Sovereignty, Compliance, and the World Trade Organization: Lessons from the History of Supreme Court Review, 20 Mich J Intl L 775 (1999). 
case before us must be considered in the light of our whole experience and not merely in that of what was said a hundred years ago." 207

\section{COUNTERVAILING VALUeS}

There are two potential countervailing values in this context: the need for uniformity in the interpretation and application of international law, and the desirability of enhancing compliance with international obligations. The dissenters in Sanchez-Llamas emphasized the first value, noting that uniformity was "an important goal of treaty interpretation," and arguing that "the ICJ's position as an international court specifically charged with the duty to interpret numerous international treaties (including the Convention) provides a natural point of reference for national courts seeking that uniformity." 208 This value was also emphasized by the U.S. Supreme Court in its early decisions in explaining why states owed more than "respectful consideration" to its decisions. In Martin v Hunter's Lessee, for example, the Court emphasized the need for uniformity in explaining why it had appellate jurisdiction over state court interpretations of federal law:

Judges of equal learning and integrity, in different states, might differently interpret a statute, or a treaty of the United States, or even the constitution itself: If there were no revising authority to control these jarring and discordant judgments, and harmonize them into uniformity, the laws, the treaties, and the constitution of the United States would be different in different states, and might, perhaps, never have precisely the same construction, obligation, or efficacy, in any two states. The public mischiefs that would attend such a state of things would be truly deplorable; and it cannot be believed that they could have escaped the enlightened convention which formed the constitution. ${ }^{209}$

This value of uniformity, however, is much weaker in the context of international adjudication (outside of the European system) than with respect to a national constitutional court like the Supreme Court. The fragmented nature of the international adjudicatory

\footnotetext{
${ }^{207} 252$ US at 433.

${ }^{208} 126 \mathrm{~S} \mathrm{Ct}$ at 2700 (Breyer, J, dissenting).

${ }^{209} 14$ US (1 Wheat) 304, 348 (1816).
} 
system, and the highly varied nature of the jurisdictional relationships within that system, makes uniformity unlikely under any circumstances. As discussed, the various tribunals can and do differ among themselves, and much of their jurisprudence is formally binding only with respect to particular parties, or is merely advisory. The ICJ's Statute, for example, provides that ICJ decisions have "binding force" only "between the parties and in respect of that particular case." 210

Although the United States participated in the international adjudicatory decisions at issue in Sanchez-Llamas, it is not a party to and does not participate in most of the international adjudicatory decisions that are issued, including most ICJ decisions. If it were bound only by the reasoning in cases in which it participated, this would do little to promote uniformity. On the other hand, it is difficult to see why the United States should be bound by the reasoning in cases litigated between other countries, with different jurisdictional relationships to the institution in question, in which the United States does not even have an opportunity to express its views. ${ }^{211}$ Of course, that sort of precedential effect is common with national courts like the U.S. Supreme Court, but, as discussed, there are fundamental differences between most international adjudicatory institutions and the Supreme Court.

In addition to uniformity, it might be argued that the internationalist approach will enhance compliance with international legal obligations. Compliance is a particular concern with international law, given the absence of strong centralized enforcement machinery. If U.S. courts played a more active role in incorporating the output of international institutions, the argument goes, it would enhance the level of compliance with international legal obligations.

One problem with this argument is that it assumes that the output of international institutions will accurately reflect international legal obligations, whereas this is not necessarily the case. It is not obvious, for example, that the ICJ did a better job than the U.S. Supreme Court of interpreting the Vienna Convention.

\footnotetext{
${ }^{210}$ ICJ Statute, Art 59.

${ }^{211}$ The arguments for uniformity may be stronger with respect to the WTO, a centralized and specialized institution with wide membership, compulsory jurisdiction over the members, and repeat players. Even for the WTO, however, Congress has required that adjudicatory decisions be filtered through the U.S. democratic process (see text accompanying note 196).
} 
Nor is it clear that the U.S. judiciary is institutionally better suited than the political branches to evaluate the content of international norms, whether treaty-based or customary. Moreover, often the goal of the internationalist conception is to advance purported goals of the international legal system where compliance is not at stake. This is the case, for example, with arguments in support of broad human rights litigation under the Alien Tort Statute-the United States is not required to provide for that litigation, and, indeed, it is almost unique in the world in doing so. ${ }^{212}$

In addition, since international law almost never requires a particular role for domestic courts, ${ }^{213}$ there is no contradiction between the constitutionalist approach and compliance. Under that approach, the political branches simply play the lead role in making compliance decisions. As noted above, this approach has not generally resulted in U.S. noncompliance with WTO obligations. Even with respect to Avena, the Executive Branch has attempted to comply with the judgment despite disagreeing with the ICJ's reasoning. Whether the United States complies with Article 36 more generally will depend on a variety of factors beyond whether this article is determined to create judicially enforceable rights (the issue left open in Sanchez-Llamas). Those factors include most notably the degree to which the federal government educates and pressures state and local governments to comply-something it has already been doing in recent years, as the ICJ itself has acknowledged..$^{214}$

Of course, one might question whether the political branches will make wise decisions about international law compliance. It is possible, for example, that the political branches will focus too much on short-term or parochial concerns, perhaps because of pressure from special interest groups. This objection, however, sweeps too broadly; taken to it logical extreme, it would suggest that U.S. courts should operate as the ultimate policymakers, a proposition at odds with the basic separation-of-powers structure

\footnotetext{
${ }^{212}$ See Beth Stephens, Translating Filartiga: A Comparative and International Law Analysis of Domestic Remedies for International Human Rights Violations, 27 Yale J Intl L 1, 17-18 (2002).

${ }^{213}$ See, e.g., Lori F. Damrosch et al, International Law: Cases and Materials 160-61 (4th ed 2001) ("International law requires a state to carry out its international obligations but, in general, how a state accomplishes that result is not of concern to international law or to the state system.").

${ }^{214}$ See LaGrand, at paras $121,123-24$ (cited in note 16 ).
} 
of the Constitution. It is also at odds with various deference doctrines, including the Chevron doctrine in administrative law, whereby courts accept Executive Branch legal interpretations on the theory that the Executive is in a better position than the courts to make the relevant policy assessments relating to the interpretations. ${ }^{215}$

In any event, there are significant reasons to question whether the courts are functionally better suited than the political branches to make international compliance decisions. Courts will typically lack much of the relevant information to assess, for example, the likely consequences of noncompliance or undercompliance, or of different forms of compliance, including effects on reciprocity and on international cooperation more generally. Moreover, there is an inherent inconsistency in this call for a greater judicial role in promoting U.S. compliance, since it implicitly assumes that the political branches will make wise decisions concerning international commitments, including commitments giving authority to international institutions, while at the same time questioning their wisdom when it comes to compliance.

\section{Conclusion}

International tribunals can often play a useful role in facilitating international cooperation. As these tribunals continue to expand in number and authority, however, it will become increasingly important to understand their proper relationship with domestic courts. Despite the Supreme Court's controversial citation of foreign and international materials in some of its constitutional law decisions, and despite recent academic calls for greater "transnational judicial dialogue," the Court indicated in Sanchez-Llamas that it will insist on a certain degree of autonomy from the international legal system. Although the Court took international law seriously, it made clear that international law and decisions will be applied in the United States against the backdrop of the usual constitutional, procedural, and remedial doctrines that govern the domestic legal system. International dialogue has a role under this approach, but it is one whereby national courts act as independent interpreters and filters of international law, rather

${ }^{215}$ See Eric A. Posner and Cass Sunstein, Chevronizing Foreign Relations Law, 116 Yale L J (forthcoming 2007). 
than as agents of the international order. This mediating role for domestic courts is normatively desirable in light of the highly fragmented and diverse nature of the international adjudicative system. 


$$
\text { . }
$$

